\title{
LOS NUEVOS PRINCIPIOS \\ DEL DERECHO DE FAMILIA
}

\section{THE NEW PRINCIPLES OF FAMILY LAW}

\section{Cristián Lepin Molina*}

\section{RESUMEN}

En este artículo se realiza un análisis crítico de los nuevos principios del Derecho de Familia, se pone de manifiesto la influencia de los derechos humanos en las grandes transformaciones del Derecho de Familia y en especial en la configuración de los nuevos principios que lo informan. Así, se brinda una sistematización de dichos principios, y se propone avanzar en su contenido e identificar sus principales manifestaciones en la legislación positiva.

Se plantea como nuevos principios del Derecho de Familia: la protección de la familia, la protección del matrimonio, la igualdad entre los integrantes del grupo familiar (de los cónyuges y de los hijos), la protección del más débil en las relaciones de familia (interés superior del niño y cónyuge más débil), la autonomía de la voluntad y, por último, el principio de intervención mínima del Estado.

Palabras clave: derecho de familia, principios, matrimonio, interés superior del niño, cónyuge más débil, igualdad, autonomía de la voluntad.

\section{Abstract}

This paper presents a critical analysis of the new principles of family law, shows the influence of Human Rights in the great transformations of

* Licenciado en Ciencias Jurídicas y Sociales, abogado, doctorando en Derecho Civil Universidad de Buenos Aires, magíster en Derecho por la Universidad de Chile, profesor de la Facultad de Derecho de la Universidad de Chile, de pre y posgrado, director(s) de la Escuela de Posgrado, de la misma universidad. Dirección postal: avenida Santa María 0200, segundo piso, Providencia, Chile. Artículo recibido el 6 de mayo de 2014 y aceptado para su publicación el 29 de agosto de 2014. Correo electrónico clepin@derecho.uchile.cl.

El autor agradece la colaboración del investigador Ignacio Araya Paredes, de la Escuela de Posgrado de la Facultad de Derecho de la Universidad de Chile. 
family law and especially in the configuration of its new principles. Insofar, a systematization of these principles is provided, and we propose to advance in their subject matter and identify their principal manifestations in positive law.

We propose as new principles of family law: the protection of the family, the protection of marriage, equity between the members of the family (spouse and children), the protection of the weakest in the family relationships (best interest of the child and weaker spouse), free will, and finally, the principle of minimum State intervention.

Keywords: family law, principles, marriage, best interest of the child, weaker spouse, equity, free will.

\section{INTRODUCCIÓN}

Las principales reformas introducidas en los últimos años a nuestro Código Civil se refieren a materias de familia, en el libro I: "De las personas" a través de una serie de normas modificatorias ${ }^{1}$. Junto con ello se han incorporado un número importante de leyes especiales o complementarias como, por ejemplo, la ley $\mathrm{N}^{\circ} 4.808$, sobre Registro Civil²; la ley $\mathrm{N}^{\circ} 14.908$, sobre Abandono de Familia y Pago de Pensiones alimenticias ${ }^{3}$; la ley $N^{\circ} 19.947$,

${ }^{1}$ Cfr. Ley de Matrimonio Civil de 10 de enero de 1884; DL No 328, de 12 de marzo de 1925; Ley $\mathrm{N}^{\circ}$ 5.521, de 19 de diciembre de 1934, que iguala a la mujer chilena ante el Derecho; ley $\mathrm{N}^{\circ}$ 5.270, de 2 de diciembre de 1935, sobre Abandono de Familia y Pago de Pensiones Alimenticias; ley $\mathrm{N}^{\circ}$ 7.612, de 21 de octubre de 1943, que introduce diversas modificaciones al Código Civil (reduce la mayoría edad a los veintiún años, suprime la muerte civil, autoriza la separación convencional de bienes durante el matrimonio, etc.); ley $\mathrm{N}^{\circ}$ 10.271, 2 de abril de 1952, que introduce diversas modificaciones al Código Civil; ley 18.802, de 9 de junio 1989, que modifica el Código Civil, el Código de Comercio y la ley N ${ }^{\circ}$ 16.618; ley $\mathrm{N}^{\circ} 19.335$, de 23 de septiembre de 1994, que establece régimen de participación en los gananciales, y modifica el Código Civil, la Ley de Matrimonio Civil, el Código Penal y otros cuerpos legales que indica; ley $\mathrm{N}^{\circ} 19.585,26$ de octubre de 1998, que modifica el Código Civily otros cuerpos legales en materia de filiación; ley $\mathrm{N}^{\circ} 19.947,17$ de mayo de 2004, que estatuye Ley de Matrimonio Civil; ley $\mathrm{N}^{\circ}$ 19.968, 30 de agosto de 2004, que crea los Tribunales de Familia; ley $\mathrm{N}^{\circ} 20.030,5$ de julio de 2005, que modifica el Código Civil, en lo relativo a la exigencia de presentación de antecedentes para dar curso a la demanda de reclamación de maternidad o paternidad, y a la valoración de los medios de prueba sobre el particular; Por último, la ley $\mathrm{N}^{\circ} 20.680$, de 21 de junio del año 2013, que introduce modificaciones al Código Civily a otros cuerpos legales, con el objetivo de proteger la integridad del menor en caso de que sus padres vivan separados.

${ }^{2}$ Publicada el 10 de febrero de 1930 (última modificación ley $\mathrm{N}^{\circ} 20.152$ de 9 de enero 2007).

${ }^{3}$ Publicada el 5 de octubre de 1962(última modificación ley $\mathrm{N}^{\circ} 19.947$ de 17 de mayo 2004). 
Nueva Ley de Matrimonio Civil ${ }^{4}$; la ley N ${ }^{\circ}$ 19.960, sobre Adopción de Menores $^{5}$; la ley $\mathrm{N}^{\circ} 19.968$, que crea los Tribunales de Familia ${ }^{6}$ y la ley $\mathrm{N}^{\circ} 20.066$, sobre Violencia Intrafamiliar ${ }^{7}$, por mencionar las más relevantes ${ }^{8}$.

Esta gran cantidad de normas modificatorias y complementarias ha generado dos consecuencias importantes:

i) un efecto de descodificación e hiperregulación del Derecho de Familia, que se inicia con la Ley de Matrimonio Civil de $1884^{9}$ y

ii) la creación de un nuevo marco normativo, que modifica de manera profunda el Derecho de Familia y los principios que históricamente han regido en nuestro ordenamiento jurídico familiar.

Así, los clásicos principios del Derecho de Familia, vigentes a partir de la fecha de entrada en vigencia del Código Civil(1857), eran los siguientes:

a) Matrimonio religioso e indisoluble;

b) Incapacidad relativa de la mujer casada;

c) Administración unitaria y concentrada en el marido de la sociedad conyugal;

d) Patria potestad fuertemente favorecida y

e) Filiación matrimonial fuertemente favorecida ${ }^{10}$.

Dichos principios, que representaban las ideas dominantes a la época de dictación del Código de Andrés Bello, han dado paso, en una larga evolución ${ }^{11}$ a los nuevos principios que gobierna esta materia y que son el objeto de nuestro estudio.

En una primera etapa, los cambios se materializan para solucionar problemas sociales, como la necesidad de mano de obra y la consecuente incorporación de la mujer al trabajo ${ }^{12}$. Dichas modificaciones no son tan profundas y se desarrollan en forma lenta y gradual. Es a partir de la aprobación por parte de nuestro país de los tratados internacionales de derechos humanos, que se acelera el proceso, con profundas transformaciones, incorporando principios generales del Derecho: igualdad, liber-

${ }^{4}$ Publicada el 17 de mayo de 2004 (última modificación ley $\mathrm{N}^{\circ} 20.680$ de 21 de junio de 2013).

${ }^{5}$ Publicada el 5 de agosto de 1999 (última modificación ley ${ }^{\circ} 19.968$ de 30 de agosto de 2004).

${ }^{6}$ Publicada el 30 de agosto de 2004 (última modificación ley $\mathrm{N}^{\circ} 20.286$ de 15 de septiembre de 2008).

${ }^{7}$ Publicada el 7 de octubre de 2005 (última modificación ley $\mathrm{N}^{\circ} 20.286$ de 15 de septiembre de 2008).

${ }^{8}$ Cfr. LePin (2014b), p. 822.

${ }^{9}$ Op. cit., p. 4.

${ }^{10}$ Ramos (2005), p. 19 y Rioseco (1956), pp. 541-560.

${ }^{11}$ Cfr. Domínguez (2005), pp. 205-218; Rioseco (1956), pp. 541-560 y Abeliuk (2009), pp. 55-70.

${ }^{12}$ Cfr. Giordano (2010), pp. 97-113. 
tad, y autonomía, que se encontraban ajenos a nuestro Derecho de Familia.

Los actuales principios del Derecho de Familia son fruto, entonces, de la incorporación de las progresivas reformas enunciadas, las que han sido generadas a la luz de los tratados sobre derechos humanos ${ }^{13}$. Estos últimos, en virtud de lo que dispone el artículo $5^{\circ}$ de la Constitución Política de la República, constituyen, por una parte, un límite al ejercicio de la soberanía y, por otra, un deber del Estado y de sus órganos, de promover y respetar los derechos esenciales que emanan de la naturaleza humana ${ }^{14}$.

En este sentido, importa determinar en primer lugar qué entendemos por principio. De esta manera, siguiendo a Ronald Dworkin, cuando hablamos de principios nos estamos refiriendo a un estándar que ha de ser observado, no porque favorezca o asegure una situación económica, política o social que se considere deseable, sino porque es una exigencia de la justicia, la equidad o alguna dimensión de la moralidad ${ }^{15}$. Para Miguel

${ }^{13}$ Cfr. Declaración Universal de Derechos Humanos. Adoptada y proclamada por la Resolución de la Asamblea General 217 A (III) del 10 de diciembre de 1948. Convención Americana sobre Derechos Humanos, denominada "Pacto de San José de Costa Rica", decreto $\mathrm{N}^{\circ}$ 873, de 23 de agosto de 1990, publicado en el Diario Oficial el 5 de enero de 1991. Pacto Internacional de Derechos Civiles y Políticos, entrada en vigor para Chile el 10 de mayo de 1972, decreto $\mathrm{N}^{\circ} 778$, de 30 de noviembre de 1976, publicado en el Diario Oficial, el 29 de abril de 1989. Pacto Internacional de Derechos Económicos, Sociales y Culturales, entrada en vigor para Chile el 10 de marzo de 1972, decreto $\mathrm{N}^{\circ} 326$, de 28 de abril de 1989, publicado en el Diario Oficial, el 27 de mayo de 1989. Convención sobre la Eliminación de todas las Formas de Discriminación contra la Mujer, Vigente para Chile desde el 6 de enero de 1990, decreto N $^{\circ} 789$ del Ministerio de Relaciones Exteriores, publicado en el Diario Oficial el 9 de diciembre de 1989. Convención Interamericana para Prevenir, Sancionar y Erradicar la Violencia Contra la Mujer, también denominada "Convención de Belem do Pará", vigente para Chile desde el 15 de diciembre de 1996, decreto No 1.640 del Ministerio de Relaciones Exteriores, publicado en el Diario Oficial el 11 de noviembre de 1998. Convención sobre los Derechos del Niño, vigente para Chile desde el 12 de septiembre de 1990, decreto No 830 del Ministerio de Relaciones Exteriores, publicado en el Diario Oficial el 27 de septiembre de 1990. Convención sobre la Obtención de Alimentos en el Extranjero, vigente para Chile desde el 9 de enero de 1961, decreto No 23 del Ministerio de Relaciones Exteriores, publicado en el Diario Oficial el 10 de enero de 1961. Convención sobre Protección del Niño y Cooperación en Materia de Adopción Internacional, vigente para Chile desde el 1 de noviembre de 1999, decreto $\mathrm{N}^{\mathrm{o}} 1.215$ del Ministerio de Relaciones Exteriores, publicado en el Diario Oficialel 4 de octubre de 1999. Convención Interamericana sobre Conflictos de Leyes en Materia de Adopción de Menores, vigente para Chile desde el 16 de febrero de 2002, decreto No 24 del Ministerio de Relaciones Exteriores, publicado en el Diario Oficial el 30 de abril de 2002. Convención sobre los Aspectos Civiles del Secuestro Internacional de Niños, vigente para Chile desde el 1 de mayo de 1994, decreto $\mathrm{N}^{\circ} 386$ del Ministerio de Relaciones Exteriores, publicado en el Diario Oficial el 17 de junio de 1994.

${ }^{14}$ LePin (2013a), pp. 95-96.

${ }^{15}$ Dworkin (1989), p. 72. 
Cillero, en el marco de un sistema jurídico basado en el reconocimiento de derechos, puede decirse que los principios son derechos que permiten ejercer otros derechos y resolver conflictos entre derechos igualmente reconocidos ${ }^{16}$.

Para Robert Alexy, en tanto, los principios "son normas que ordenan que algo sea realizado en la mayor medida posible, dentro de las posibilidades jurídicas y reales existentes" ${ }^{17}$.

Desde nuestro punto de vista se trata de un mandato dirigido al juez para darle contenido a la ley en el caso concreto, es decir, para que sobre la base de una determinada orientación resuelva el caso, por decirlo de una manera, legislando en cada supuesto en particular. Lo que implica un reconocimiento, por parte del legislador, de sus limitaciones, en el sentido de que no puede prever todas las situaciones, y que debe depositar la confianza en el juez para que adopte la decisión más conveniente ${ }^{18}$.

A continuación, se realizará un análisis de los nuevos principios del Derecho de Familia y se propone la siguiente sistematización: principio de protección a la familia, protección al matrimonio, principio de igualdad (de los cónyuges y de los hijos), protección del más débil (interés superior del niño y cónyuge más débil), autonomía de la voluntad y, por último, el principio de intervención mínima del Estado.

\section{PRINCIPIO DE PROTECCIÓN A LA FAMILIA}

La importancia de la familia queda consagrada en la mayoría de los tratados internacionales sobre derechos humanos. Así, por ejemplo, la Declaración Universal de los Derechos Humanos, artículo 16.3, se dispone: "la familia es el elemento natural y fundamental de la sociedad y tiene derecho a la protección de la sociedad y del Estado"19.

${ }^{16}$ Cillero (2007), p. 133.

${ }^{17}$ AleXy (2008), p. 67.

${ }^{18}$ LePin (2013b), p. 515.

${ }^{19}$ En términos similares, el Pacto Internacional de Derechos Civiles y Políticos, en el artículo 23.1, señala: "la familia es el elemento natural y fundamental de la sociedad y tiene derecho a la protección de la sociedad y del Estado". Por su parte, el Pacto Internacional de Derechos Económicos, Sociales y Culturales, en el artículo 10.1, prescribe: "se debe conceder a la familia, que es el elemento natural y fundamental de la sociedad, la más amplia protección y asistencia posible, especialmente para su constitución y mientras sea responsable del cuidado y la educación de los hijos a su cargo. El matrimonio debe contraerse con el libre consentimiento de los futuros cónyuges". Y, por último, en la Convención sobre Derechos Humanos denominada "Pacto de San José de Costa Rica", en el artículo 17.1, se establece: "la familia es el elemento natural y fundamental de la sociedad y debe ser protegida por la sociedad y el Estado". 
Por su parte, el preámbulo de la Convención sobre los Derechos de los Niños reitera el deber de protección de la familia, al señalar:

"convencidos de que la familia, como grupo fundamental de la sociedad y medio natural para el crecimiento y el bienestar de todos sus miembros, y en particular de los niños, debe recibir la protección y asistencia necesarias para poder asumir plenamente sus responsabilidades dentro de la comunidad".

Luego agrega:

"reconociendo que el niño, para el pleno y armonioso desarrollo de su personalidad, debe crecer en el seno de la familia, en un ambiente de felicidad, amor y comprensión"20.

Por su parte, nuestra Constitución Política, ya en el artículo $1^{\circ}$ inciso $2^{\circ}$, prescribe: "la familia es el núcleo fundamental de la sociedad". En el inciso $5^{\circ}$, agrega:

"es deber del Estado resguardar la seguridad nacional, dar protección a la población y a la familia, propender al fortalecimiento de ésta, promover la integración armónica de todos los sectores de la Nación y asegurar el derecho de las personas a participar con igualdad de oportunidades en la vida nacional" ${ }^{21}$.

Para Javier Barrientos:

"la familia y la vida en ella constituyen un espacio vital en el que las personas pueden perseguir y alcanzar 'su mayor realización es-

${ }^{20}$ En el artículo $7^{\circ}$, la Convención indica: “1. El niño será inscrito inmediatamente después de su nacimiento y tendrá derecho desde que nace a un nombre, a adquirir una nacionalidad y, en la medida de lo posible, a conocer a sus padres y a ser cuidado por ellos.

2. Los Estados Partes velarán por la aplicación de estos derechos de conformidad con su legislación nacional y las obligaciones que hayan contraído en virtud de los instrumentos internacionales pertinentes en esta esfera, sobre todo cuando el niño resultara de otro modo apátrida.

$\mathrm{Y}$ en el artículo $8^{\circ}$, prescribe: 1 . Los Estados Partes se comprometen a respetar el derecho del niño a preservar su identidad, incluidos la nacionalidad, el nombre y las relaciones familiares de conformidad con la ley sin injerencias ilícitas.

3. Cuando un niño sea privado ilegalmente de algunos de los elementos de su identidad o de todos ellos, los Estados Partes deberán prestar la asistencia y protección apropiadas con miras a restablecer rápidamente su identidad".

${ }^{21} \mathrm{El}$ destacado es nuestro. 
piritual y material posible' y, desde esa perspectiva, la citada base de la institucionalidad que se declara en el inciso $3^{\circ}$ del artículo $1^{\circ}$ de la Constitución Política de la República informa y explica el que la familia ocupe un lugar central en el derecho de las personas, en cuanto a que todas tienen un determinado status familiae"22.

La importancia de la familia queda de manifiesto, también, en la historia de la ley $\mathrm{N}^{\circ} 19.947$, NLMC, en la que se sostiene:

"la familia constituye un lugar central y decisivo en la experiencia humana. La identidad y la intimidad de los hombres y las mujeres se forjan y se desarrollan en la familia. Los sentimientos de felicidad o infelicidad de las personas están fuertemente asociados a la vida familiar. Esta es un instrumento privilegiado de socialización de las nuevas generaciones. A través suyo se transmiten creencias, valores, usos y costumbres" 23 .

De esta forma, la familia es la institución que mejor cumple con las funciones esenciales para el desarrollo de todo ser humano, a saber: la función biológica (sexual y reproductiva), educativa (socializa a los niños en cuanto a conductas, hábitos y valores), económicas (alimentación, salud, habitación, vestuario y recreación) y la función protectora (seguridad y cuidados de sus integrantes, principalmente de los más débiles, niños, ancianos e incapaces).

Para Jorge del Picó:

"la defensa de la familia es una consecuencia del interés público en su protección jurídica, originada en su apreciación como institución social y que se manifiesta, entre otras facetas de tutela, en la indisponibilidad de las normas del Derecho matrimonial como parte integrante del Derecho de familia. Las características relevantes derivadas de su consideración como institución social, radican en la interdependencia entre las personas que la integran y su común sujeción a una finalidad superior, que legitiman la indisponibilidad normativa señalada" 24 .

22 Barrientos (2011), p. 3.

${ }^{23}$ Moción de los honorables diputados: Isabel Allende Bussi, Mariana Aylwin Oyarzún, Carlos Cantero Ojeda, Sergio Elgueta Barrientos, Víctor Jeame Barrueto, Eugenio Munizaga Rodríguez, María Antonieta Saa, José Antonio Viera-Gallo Quesney e Ignacio Walker Prieto. Boletín N $\mathrm{N}^{\circ}$ 1759-18, 28 de noviembre de 1995. BIBLIOTECA DEL Congreso Nacional (2004), p. 5.

${ }^{24}$ Del Picó (2010), pp. 119-120. 
Agrega:

"la importancia de la familia como institución social no es cuestionada mayoritariamente ni en la doctrina ni en el debate público, centrándose la controversia en el concepto de familia y en su naturaleza jurídica"25.

La controversia planteada versa principalmente sobre si el Estado debe proteger a la familia constituida de modo legal, a través del matrimonio, o si el concepto es más amplio y la protección debe alcanzar también a la denominada familia natural o de hecho ${ }^{26}$. Se trata de un tema que supera los límites de este trabajo, aunque es necesario consignar que existen a lo menos seis proyectos de ley para regular las relaciones de hecho ${ }^{27}$, y que el proyecto de AVP ha presentado avances en su tramitación ${ }^{28}$.

Por otra parte, resulta importante reflexionar sobre el sentido y alcance de las expresiones del artículo $1^{\circ}$ de la Constitución Política de la República, en cuanto a que "es deber del Estado dar protección a la familia" y "propender al fortalecimiento de ésta".

En cuanto al deber del Estado de dar protección a la familia, podríamos decir que la norma constitucional obliga a todos los poderes del Estado. 16 En este sentido, tanto el Poder Ejecutivo como Legislativo deberán dictar normas que integren el estatuto protector de la familia ${ }^{29} \mathrm{y}$ al Poder Judicial concretar dicha protección al aplicar la normativa específica.

Así lo entiende Eduardo Soto Kloss:

"el estado tiene el deber jurídico/obligación de proteger a la familia y de propender a su fortalecimiento, y ello en toda actividad estatal,

${ }^{25}$ Del Picó (2010), p. 120. Sobre el concepto de familia cfr. Somarriva (1963), p. 10. En similar sentido Alessandri (1941), p. 5; Rossel (1958), p. 9; Meza (1989), pp. 12-13; Ramos (2005), p. 11 y Corral (1994), pp. 2-5. Sobre la naturaleza jurídica de la familia cfr. Corral (1994), p. 15 y ss; Córdoba (dir.) (2005), p. 6 y ss; Méndez Costa et al. (2008), p. 27 y ss; ZANNONI (2006), p. 18 y ss.

${ }^{26}$ Cfr. Figueroa (1995), pp. 65-95; Corral (1994), pp. $31-72$ y Soto Kloss (1994), pp. 217-225.

${ }^{27}$ Boletín 5623-07, proyecto de ley que crea la figura de unión civil en los gananciales; Boletín $\mathrm{N}^{\circ} 6735-07$, proyecto de ley que establece un pacto de unión civil; Boletín $\mathrm{N}^{\circ} 6846$ 07 , proyecto de ley que regula los pactos de uniones civiles; Boletín $\mathrm{N}^{\circ} 6955-07$, proyecto de ley de no discriminación y a favor de los derechos de las parejas del mismo sexo; Boletín $\mathrm{N}^{\circ} 7011-07$, proyecto de ley de acuerdo de vida en común y Boletín $\mathrm{N}^{\circ} 7873-07$, proyecto de ley sobre acuerdo de vida en pareja, los dos últimos refundidos y en actual tramitación.

${ }_{28}$ Véase tramitación en www.senado.cl/appsenado/templates/tramitacion/index. php?boletin_ini=7011-0. [Fecha de consulta: 18 de agosto de 2014].

${ }^{29}$ En esta materia resulta relevante destacar el título II: "De la protección a la maternidad, la paternidad y la vida familiar” del Código del Trabajo, artículo 194 y ss. 
sea en su función legislativa a través de leyes que la protejan y fortalezcan, como en su función administrativa a través de la aplicación de aquéllas y de las medidas específicas que deba adoptar en su misión de satisfacer las necesidades públicas concretas a través de la prestación de bienes y servicios; pero también esa obligación pesa sobre el órgano jurisdiccional y contralor, puesto que ellos también son, obviamente, órganos del Estado"30.

En cuanto a propender al fortalecimiento de la familia, nos parece que tanto las normas como las políticas públicas deben ir encaminadas a mantener y reforzar los vínculos familiares, velando por el interés familiar, pero con pleno respeto a los derechos fundamentales de sus integrantes.

El ámbito de protección, desde la perspectiva de las normas civiles, está determinado por la existencia del matrimonio, las normas sobre filiación, los alimentos, los derechos sucesorios e, incluso, sobre violencia intrafamiliar. En conjunto, integran un estatuto protector de las relaciones familiares.

En cuanto a la concreción de este principio en la NLMC se reitera en el artículo $1^{\circ}$ lo establecido en la Constitución: "la familia es el núcleo fundamental de la sociedad" y que "el matrimonio es la base principal de la familia". Protege a la familia, incluso más allá de la ruptura matrimonial, de acuerdo con lo prescrito por el artículo $3^{\circ}$ de la NLMC:

"asimismo, el juez resolverá las cuestiones atinentes a la nulidad, la separación o el divorcio, conciliándolas con los derechos y deberes provenientes de las relaciones de filiación y con la subsistencia de una vida familiar compatible con la ruptura o la vida separada de los cónyuges".

En el mismo sentido, la NLMC privilegia la resolución alternativa de conflictos a través de mecanismos como la conciliación y la mediación (arts. 67, 69 y 90 de la NLMC). De igual forma la LTF privilegia las soluciones colaborativas entre los integrantes del grupo familiar, buscando evitar o mitigar la confrontación entre ellos (art. $14^{31}$ de la LTF) además de promover la conciliación y la mediación como formas alternativas de resolución del conflicto familiar (57 inciso $2^{\circ}, 61 \mathrm{~N}^{\mathrm{o}_{\mathrm{s}}} 4$ y 5 , y 103 y ss. de la LTF).

Por su parte, el Código Civil establece la obligación de proporcionar alimentos a los parientes en el artículo 321 , salvo en el $\mathrm{N}^{\circ} 5$ que se refiere

${ }^{30}$ Soto KLOSS (1994), p. 224.

${ }^{31}$ Artículo 14 ley $\mathrm{N}^{\circ}$ 19.968: “Colaboración. Durante el procedimiento y en la resolución del conflicto, se buscarán alternativas orientadas a mitigar la confrontación entre las partes, privilegiando las soluciones acordadas por ellas". 
al que hizo una donación cuantiosa. En estos casos la ley considera la obligación alimentaria recíproca respecto de los cónyuges, descendientes, ascendientes y hermanos. Como señala Juan Orrego:

"la obligación de dar alimentos, salvo calificadas excepciones, tiene su origen en el parentesco (lo que demuestra que constituyen una manifestación del principio de protección a la familia y en especial del principio del interés superior de los menores)" 32 .

La concreción del principio de protección de la familia en materia sucesoria se manifiesta través de las asignaciones forzosas, reguladas en el artículo 1167 del Código Civil, los alimentos que se deben por ley a ciertas personas (art. $321 \mathrm{del} C C$ ), las legítimas (arts. 1181 y $1182 \mathrm{del} C C$ ) y la cuarta de mejoras en la sucesión de los descendientes, de los ascendientes y del cónyuge (art. $1195 \mathrm{del} C C$ ), en la sucesión testada, y de los órdenes sucesorios en la sucesión intestada (art. 983 y ss. del $C C$ ). Todas estas asignaciones se establecen en relación con el grado de parentesco para los descendientes, ascendientes y el cónyuge sobreviviente ${ }^{33}$. Desde este punto de vista, el Derecho Sucesorio se transforma en el principal efecto del Derecho de Familia, cuyas normas son irrenunciables para los integrantes del grupo familiar, por tanto, de orden público ${ }^{34}$.

Por último, la protección de la integridad física y psicológica de los integrantes de la familia, se materializa primero a través de la ley $\mathrm{N}^{\circ}$ 19.325, de 27 de agosto de 1994, que se mantuvo en vigencia hasta el 7 de octubre de 2005, fecha en que comienza a regir la actual ley $\mathrm{N}^{\circ} 20.066$, que tiene por objetivo prevenir, sancionar y erradicar la violencia intrafamiliar y otorgar protección a las víctimas de la misma (art. $1^{\circ}$ ). Con el mismo objetivoo se ratifica la Convención Interamericana para Prevenir, Sancionar y Erradicar la Violencia contra la Mujer ("Convención de Belem Do Pará”), de 9 de junio de 1994 (decreto Ministerio de Relaciones Exteriores $N^{\circ} 1.640$, Diario Oficial, 11 de noviembre de 1998).

El papel de nuestra jurisprudencia ha sido activo, pronunciándose en diversas materias como, por ejemplo:

i) casos de susceptibilidad de adopción, en el sentido de dar protección a la familia y realizar todas las acciones tendientes a procurar que ella se mantenga ${ }^{35}$

32 Orrego (2007), p. 11.

${ }^{33}$ LEPIN (2013c), p. 76.

${ }^{34}$ Op. cit., p. 78.

${ }^{35}$ Plaza Oviedo con [no se consigna] (2010); [No se consignan partes. Declaración de susceptibilidad de adopción (1)] (2012); y [No se consignan partes. Declaración de susceptibilidad de adopción (2)] (2012). 
ii) a propósito de la compensación económica, para consignar que el cónyuge más débil debe ser compensado por haber privilegiado el cuidado de los hijos y del hogar común a fin de fortalecer la familia $^{36}$

iii) También en la declaración de bien familiar que tienen por finalidad principal amparar el hogar de la familia, presupuesto que no desaparece por la sola circunstancia de declararse el divorcio ${ }^{37}$

iv) en el contexto de lesiones menos graves por violencia intrafamiliar, en el sentido de rechazar el acuerdo reparatorio en protección de la víctima y de la familia ${ }^{38} \mathrm{y}$

v) por último, en un tema cada vez más frecuente, para denegar el ingreso o decretar la expulsión de ciudadanos extranjeros se ha privilegiado su situación familiar, evitando la disgregación de la familia ${ }^{39}$.

\section{PRINCIPIO DE PROTECCIÓN AL MATRIMONIO}

El matrimonio alcanza consagración en los principales tratados sobre derechos humanos, así, por ejemplo, la Declaración Universal de los Derechos Humanos, en el artículo 16.1, señala:

"los hombres y las mujeres, a partir de la edad núbil, tienen derecho, sin restricción alguna por motivos de raza, nacionalidad o religión, a casarse y fundar una familia, y disfrutarán de iguales derechos en cuanto al matrimonio, durante el matrimonio y en caso de disolución del matrimonio".

Y en el artículo 16.2, agrega: "sólo mediante libre y pleno consentimiento de los futuros esposos podrá contraerse el matrimonio" ${ }^{40}$.

${ }^{36}$ Rojas Carvajal con Román Beltraim (2008) y Suárez Cabrera con Larrañaga González (2008).

${ }^{37}$ Hidalgo Muñoz con González Barahona (2014).

${ }^{38}$ Ministerio Público con Ojeda Ortiz (2009).

${ }^{39}$ Tirado Guevara con Departamento de Extranjería y Migración (2006); Morales García con Departamento de Extranjería y Migración (2013); Leiva Falinich con Departamento de Extranjería y Migración (2013); Olaechea Vásquez con Departamento de Extranjería y Migración (2014) y Soufien Lahouel con Ministerio de Relaciones Exteriores (2014).

${ }^{40}$ En un sentido similar, el Pacto Internacional de Derechos Civiles y Políticos señala en su artículo 23.2: "se reconoce el derecho del hombre y de la mujer a contraer matrimonio y a fundar una familia si tiene edad para ello". Y en el $\mathrm{N}^{\circ} 3$, agrega: "el matrimonio no podrá celebrarse sin el libre y pleno consentimiento de los contrayentes". Por su parte 
En España se ha sostenido:

"el artículo 12 del Convenio europeo para la protección de los derechos humanos y de las libertades fundamentales, de 4 de noviembre de 1950, establece que 'a partir de edad núbil, el hombre y la mujer tienen derecho a casarse y a fundar una familia según las leyes nacionales que rijan el ejercicio de este derecho'. Esta disposición ha llevado a considerar en algunos países que el derecho a contraer matrimonio se incluye entre los derechos fundamentales del hombre, aunque directamente no aparezca mencionado en la lista de los mismos" ${ }^{\prime 1}$.

En este orden de ideas según la NLMC, en el artículo $1^{\circ}$ : "el matrimonio es la base principal de la familia”. Con esta aseveración, el matrimonio es la forma principal de constituir familia, con lo cual reconoce que hay otras formas de constituir familia como las uniones de hecho, las familias monoparentales o las familias ensambladas.

Para Maricruz Gómez de la Torre,

"si hacemos una evaluación de la Nueva Ley de Matrimonio 20 Civil, podemos concluir que valora y promueve la preservación del matrimonio" 42 .

Esto se confirma en cuanto no incluyó el artículo 102 entre las modificaciones que realizó a algunos artículos del Código Civil. Este artículo es el que prescribe que el matrimonio es "un contrato solemne por el cual un hombre y una mujer se unen actual e indisolublemente y por toda la vida...”.

De acuerdo con la nueva regulación del matrimonio, el ius connubis adquiere una especial protección por el artículo $2^{\circ}$ de la NLMC que dispone:

el Pacto internacional de derechos económicos, sociales y culturales, en el artículo 10.1, prescribe que "se debe conceder a la familia, que es el elemento natural y fundamental de la sociedad, la más amplia protección y asistencia posible, especialmente para su constitución y mientras sea responsable del cuidado y la educación de los hijos a su cargo. El matrimonio debe contraerse con el libre consentimiento de los futuros cónyuges". Por último, en la Convención sobre Derechos Humanos denominada "Pacto de San José de Costa Rica", se establece, en el artículo 17.1: "se reconoce el derecho del hombre y la mujer a contraer matrimonio y a fundar una familia si tienen la edad y las condiciones requeridas para ello por las leyes internas, en la medida en que éstas no afecten al principio de no discriminación establecido en esta Convención". Y en su $\mathrm{N}^{\circ} 3$, que "el matrimonio no puede celebrar sin el libre y pleno consentimiento de los contrayentes".

${ }^{41}$ Roca (1999), p. 93.

${ }^{42}$ Gómez de la Torre (2009), pp. 64-65. 
"la facultad de contraer matrimonio es un derecho esencial inherente a la persona humana, si se tiene edad para ello. Las disposiciones de esta ley establecen los requisitos para asegurar el libre y pleno consentimiento de los contrayentes".

Incluso, consagra una acción popular para salvaguardar el derecho a contraer matrimonio de cualquier acto arbitrario, ya sea de autoridad o de un particular, según dispone el mismo artículo $2^{\circ}$, en su inciso $2^{\circ}$ :

"el juez tomará, a petición de cualquier persona, todas las providencias que le parezcan convenientes para posibilitar el ejercicio legítimo de este derecho cuando, por acto de un particular o de una autoridad, sea negado o restringido arbitrariamente".

Para concretar este principio, la NLMC consagra una serie de herramientas orientadas a obtener un consentimiento más serio e informado y para procurar mantener o recomponer el vínculo matrimonial.

En primer lugar, aumenta la edad para contraer matrimonio, de doce años las mujeres y catorce los hombres, a dieciséis años para ambos, considerando un mayor grado de madurez psicológica y no solo la madurez sexual, en cuanto les habilita para procrear (art. $5 \mathrm{~N}^{\circ} 2$ de la NLMC). Por otra parte, se establece el deber del oficial del Registro Civil de proporcionar información sobre los derechos y deberes de carácter personal entre los cónyuges y sobre los regímenes patrimoniales (art. 10, inciso $1^{\circ}$ de la NLMC). Por último, se incorporan los denominados "cursos de preparación del matrimonio" que tienen por objetivo promover la libertad y seriedad del consentimiento matrimonial, particularmente con los derechos y deberes que genera el vínculo (arts. 10 y 11 de la NLMC).

En segundo lugar, privilegia la preservación del vínculo matrimonial como se desprende de lo dispuesto en el art. $3^{\circ}$ de la NLMC, regulando que en los juicios de separación, nulidad y divorcio,

“conociendo de estas materias, el juez procurará preservar y recomponer la vida en común en la unión matrimonial válidamente contraída, cuando ésta se vea amenazada, dificultada o quebrantada”.

En el mismo sentido, el art. 67 de la NLMC dispone:

"solicitada la separación, sea que la demanda se presente directamente o de conformidad al artículo 29, o el divorcio, el juez, durante la audiencia preparatoria, deberá instar a las partes a una conciliación, examinando las condiciones que contribuirían 
a superar el conflicto de la convivencia conyugal y verificar la disposición de las partes para hacer posible la conservación del vínculo matrimonial".

El ámbito de protección durante la vigencia del matrimonio se genera a partir de una serie de efectos patrimoniales que la doctrina ha denominado estatuto protector del matrimonio, que según Álvaro Vidal:

"confiere a ambos cónyuges una dosis de seguridad, sobre todo aquel que, durante su vigencia, se sacrifica en una mayor medida por dedicarse a las labores del hogar común y/o al cuidado de los hijos, dejando de desarrollar una actividad remunerada. Entre las expectativas se cuentan, el título legal para demandar alimentos, los regímenes matrimoniales del tipo participativo, como la sociedad conyugal y la participación en los gananciales, la posibilidad de demandar la declaración de un bien familiar, la cobertura de los sistemas de seguridad social y de salud, y los derechos sucesorios que la ley reconoce para el caso de fallecimiento" ${ }^{43}$.

Sin lugar a dudas, el conjunto de derechos y obligaciones de carácter patrimonial cuya titularidad y ejercicio se funda en la existencia del matrimonio, denominado estatuto protector, se encuentra disperso en nuestro ordenamiento jurídico, como el derecho de alimentos para el cónyuge (art. 321 y ss. del $C C$ y en la ley $\mathrm{N}^{\circ} 14.908$ ), el régimen de sociedad conyugal (art. 1715 y ss. del $C C$ ) y el régimen de participación en los gananciales (art. 1792-1 y ss. del CC).

El derecho de alimentos se presenta como una forma de proteger, en este caso, al cónyuge que se encuentre en estado de necesidad, que no pueda subsistir sin la ayuda económica del otro cónyuge, lo que se debe solicitar al juzgado de familia correspondiente. Por su parte, los regímenes patrimoniales de carácter participativo, son expresión de la solidaridad familiar y de la protección del patrimonio familiar, a través de los gananciales en la sociedad conyugal o de la determinación del crédito de participación en el régimen de participación en los gananciales.

Dentro de este estatuto protector se deben considerar, además, los bienes familiares que el Código Civil regula a favor de uno de los cónyuges en las hipótesis descritas en los artículos 141 a 149. Se ha sostenido:

“con el nombre de 'bienes familiares' se designan ciertas cosas inmuebles o muebles que cumplen una función familiar, y a las

${ }^{43}$ VIDAL (2006), p. 225. 
que, por ello, la ley las somete a un estatuto normativo especial, con independencia del régimen económico elegido por los cónyuges" ${ }^{34}$.

En cuanto a su función protectora, Hernán Corral señala:

"los bienes son calificados de familiares porque la ley les reconoce una función esencial con la vida cotidiana de la familia y por ello los somete a una protección especial. Esta protección se traduce básicamente en tres aspectos: $1^{\circ}$ ) la gestión pasa a ser compartida entre el cónyuge propietario y el cónyuge no propietario; $2^{\circ}$ ) se posibilita la constitución de derechos reales de goce a favor del cónyuge no propietario, y $3^{\circ}$ ) los bienes son puestos a resguardo de las acciones de los acreedores del cónyuge dueño, mediante una especie de ejecución subsidiaria" ${ }^{45}$.

Por último, el Derecho Sucesorio establece un rango de protección importante para el cónyuge sobreviviente, ya que en la sucesión testada es legitimario por lo que el causante debe respetar su asignación que corresponde, y puede ser beneficiado con parte o la totalidad de la cuarta de mejoras (art. $1195 \mathrm{del} C C$ ) y, eventualmente, de la cuarta de libre disposición ${ }^{46}$.

En la sucesión intestada concurre en el primer orden de sucesión con los descendientes, y le corresponde el doble de lo que por legitima rigurosa o efectiva corresponda a cada hijo, salvo que hubiere un hijo, en este caso su cuota será igual a la legítima rigorosa o efectiva del hijo (art. 988 del CC). Si el causante no tiene descendientes, concurre en el segundo orden de sucesión con los ascendientes; en este caso la herencia se divide en tres partes, dos para el cónyuge y una para los ascendientes, a falta de estos, llevará todos los bienes el cónyuge (art. 989 del $C C{ }^{47}$.

En la etapa de partición de la comunidad hereditaria, el cónyuge sobreviviente tiene derecho a que su cuota se entere con preferencia mediante la adjudicación a favor suyo de la propiedad inmueble en que resida y que sea o haya sido la vivienda principal de la familia, así como los bienes muebles que la guarnecen. Si el valor de dichos bienes excede la cuota hereditaria, el cónyuge sobreviviente puede solicitar que se constituya en su favor derechos de habitación y de uso, de carácter gratuito y vitalicio $\left(\text { art. } 1337 \mathrm{~N}^{\circ} 10 \mathrm{del} C C\right)^{48}$.

${ }^{44}$ Corral (2007), p. 53.

${ }^{45}$ Op. cit., p. 54.

${ }^{46}$ LEPIN (2013c), p. 77.

${ }^{47}$ Ibid.

${ }^{48}$ Cfr. Corral (edit.) (2000), p. 251 y Corral (2005), p. 219. 
Este conjunto de derechos son indisponibles para los cónyuges durante el matrimonio, por tanto se encuentran excluidos de la autonomía de la voluntad. Si se quiere, conforman el orden público familiar.

Por último, la ley $\mathrm{N}^{\circ} 4.808$ sobre Registro Civil, exhibe una serie de disposiciones bajo el título "Medidas que favorecen la constitución legal de la Familia", artículos 51 a 55, en que se establece la obligación de los oficiales del Registro Civil de visitar sus respectivas comunas a fin de procurar la celebración del matrimonio del hombre y la mujer que, haciendo vida marital, tengan hijos comunes ${ }^{49}$.

\section{PRINCIPIO DE IGUALDAD}

En la Declaración Universal de los Derechos Humanos, se puede leer:

"considerando que la libertad, la justicia y la paz en el mundo tienen por base el reconocimiento de la dignidad intrínseca y de los derechos iguales e inalienables de todos los miembros de la familia humana".

Luego, en el artículo $1^{\circ}$, prescribe:

"todos los seres humanos nacen libres e iguales en dignidad y derechos y, dotados como están de razón y conciencia, deben comportarse fraternalmente los unos con los otros" ${ }^{~}$.

${ }^{49}$ Artículo 51. "Los Oficiales del Registro Civil visitarán su respectiva comuna o sección, en la forma que determine el reglamento, a fin de procurar la celebración del matrimonio del hombre y la mujer que, haciendo vida marital, tengan hijos comunes.

Durante su visita, harán las inscripciones de nacimiento que procedan, denunciarán aquellos que no se hubieren inscrito en época oportuna y cuidarán de que esas inscripciones se verifiquen".

${ }^{50}$ En el mismo sentido, el Pacto Internacional de Derechos Civiles y Políticos artículo $3^{\circ}$ :

"Los Estados Partes en el presente Pacto se comprometen a garantizar a hombres y mujeres la igualdad en el goce de todos los derechos civiles y políticos enunciados en el presente Pacto".

Pacto Internacional de Derechos Económicos, Sociales y Culturales, en el artículo $3^{\circ}$, señala:

"Los Estados Partes en el presente Pacto se comprometen a asegurar a los hombres y a las mujeres igual título a gozar de todos los derechos económicos, sociales y culturales enunciados en el presente Pacto".

En la Convención sobre derechos humanos denominada "Pacto de San José de Costa Rica”, se prescribe, en el artículo $1^{\circ} .1$ :

"Los Estados Partes en esta Convención se comprometen a respetar los derechos y libertades reconocidos en ella y a garantizar su libre y pleno ejercicio a toda persona que esté sujeta a su jurisdicción, sin discriminación alguna por motivos de raza, color, sexo, 
El principio de igualdad también se encuentra establecido en nuestra Carta Fundamental, así se desprende del artículo 1, que sostiene: "las personas nacen libres e iguales en dignidad y derechos". Por su parte, el artículo $19 \mathrm{~N}^{\circ} 2$ dispone:

"La Constitución asegura a todas las personas: No 2 La igualdad ante la ley. En Chile no hay persona ni grupo privilegiados... Ni la ley ni autoridad alguna podrán establecer diferencias arbitrarias”.

Según nuestra jurisprudencia, la igualdad

“consiste en que las normas jurídicas deben ser iguales para todas las personas que se encuentran en las mismas circunstancias y que no deben concederse privilegios ni imponerse obligaciones a unos que no beneficien o graven a otros que se hallen en condiciones similares" $"$.

Según Maricruz Gómez de la Torre:

"la igualdad se expresa en dos dimensiones: de una parte, debe corregir las desigualdades de hecho, producto de situaciones que derivan de causas naturales o de la realidad social, y, de otra, debe eliminar toda diferencia arbitraria o discriminación" 52 .

Luego, agrega:

"Una diferenciación es discriminatoria si carece de justificación objetiva y razonable, es decir, si no persigue un fin legítimo o si carece de una relación razonable de proporcionalidad entre los medios empleados y el fin perseguido" 53 .

En consecuencia, las discriminaciones establecidas en razón del sexo o del nacimiento son arbitrarias y deben quedar excluidas de nuestro ordenamiento jurídico, incluidas las relaciones familiares.

En Derecho de Familia este principio general de la legislación se mantuvo distante, dado que el modelo de familia patriarcal estructurado por

idioma, religión, opiniones políticas o de cualquier otra índole, origen nacional o social, posición económica, nacimiento o cualquier otra condición social”.

${ }^{51}$ Sáez con Fisco de Chile (2001).

${ }^{52}$ Gómez de la Torre (2007), p. 36.

${ }^{53}$ Ibid. 
Andrés Bello fue establecido sobre la base de la potestad del marido/padre sobre la persona y bienes de su mujer e hijos. Lo que se mantuvo vigente hasta solo hace unos años, en que se empiezan a incorporar criterios de igualdad en las relaciones familiares. Primero a través de la ley $\mathrm{N}^{\circ} 19.335$, de 23 de septiembre de 1994, que modificó los efectos personales del matrimonio a fin de establecer en forma igualitaria las obligaciones y derechos de carácter personal entre los cónyuges, y luego la entrada en vigencia de la ley $\mathrm{N}^{\circ}$ 19.585, que modificó el Código Civily otros cuerpos legales en materia de filiación, de 26 de octubre de 1998, consagrando la plena igualdad de los hijos. Recientemente, por la ley $\mathrm{N}^{\circ} 20.680$, de 21 de junio de 2013, que deja en situación de plena igualdad a los padres respecto al cuidado personal de sus hijos.

Con respecto al modelo de familia, Manuel Somarriva opina:

"dentro de esta última concepción del grupo familiar ha existido una marcada e innegable evolución. En los comienzos se caracterizaba por ser un grupo compacto, férreamente unido, en el cual pesaba sin contrapeso la autoridad del padre y marido. Hoy en día, en cambio, asistimos a un debilitamiento de la autoridad paterna y marital, fenómeno que se justifica, tanto por las ideas 26 liberales que han dominado en el mundo desde el siglo pasado, cuanto por razones económicas: la mujer se ha incorporado de lleno a las actividades industriales, profesionales y culturales, y los hijos, por las exigencias de la vida, desde temprana edad van a las fábricas y talleres a procurarse el pan de cada día y a obtener cierta independencia económica del todo incompatible con una autoridad paterna ejercida en forma rígida e inflexible" ${ }^{54}$.

En igual sentido, se puede leer a Luis Díez-Picazo y Antonio Gullón:

"en el Derecho de los últimos tiempos los criterios estrictamente jerárquicos han ido declinando y han ido siendo sustituidos por criterios igualitarios y asociativos. En este marco se inscriben los movimientos feministas o de liberación de la mujer y los que pretenden dinamizar a la juventud y otorgarle un mayor grado de independencia, convirtiendo la potestad de los padres en simple función tuitiva" ${ }^{55}$.

De forma que la potestad ha ido dando paso progresivamente a la igualdad de los integrantes del grupo familiar, lo que se materializa en la

${ }^{54}$ SOMARRIVA (1963), p. 10.

${ }^{55}$ Díez-Picazo y Gullón (2006), p. 33. 
distribución igualitaria de las obligaciones y derechos entre los cónyuges, desde el punto de vista personal y patrimonial y en sus relaciones respecto de sus hijos, como se verá a continuación.

\section{a) Principio de igualdad entre los cónyuges}

Sin duda la igualdad entre hombres y mujeres es un principio que ha tenido un importante desarrollo en los derechos civiles y políticos, con gran influencia de los instrumentos internacionales. En las relaciones familiares todavía quedan importantes diferencias principalmente en el régimen de sociedad conyugal.

En este sentido, para Rodrigo Barcia:

"el principio de igualdad lleva a que el contenido del Derecho de Familia propenda al desarrollo libre de la personalidad de los cónyuges, que se traduce en que los hombres y mujeres tienen iguales derechos y deberes en el matrimonio y con relación a los hijos" ${ }^{56}$.

Para Claudia Schmidt:

la "igualdad entre el hombre y la mujer en lo que respecta a la comunidad de intereses y complementariedad que importa el vínculo matrimonial y que se plasma o al menos debiera manifestarse, en un sistema económico patrimonial del matrimonio que respete la personalidad jurídica individual de cada uno de los componentes de la unión matrimonial" ${ }^{57}$.

Por su parte, específicamente dirigida a la protección de los derechos de la mujer, la Convención sobre la Eliminación de Todas las Formas de Discriminación contra la Mujer versa en su artículo $1^{\mathrm{o}}$ :

“a los efectos de la presente Convención, la expresión 'discriminación contra la mujer' denotará toda distinción, exclusión o restricción basada en el sexo que tenga por objeto o por resultado menoscabar o anular el reconocimiento, goce o ejercicio por la mujer, independientemente de su estado civil, sobre la base de la igualdad del hombre y la mujer, de los derechos humanos y las libertades fundamentales en las esferas política, económica, social, cultural y civil o en cualquier otra esfera".

\footnotetext{
${ }^{56}$ BARCIA (2011), p. 25.

${ }^{57}$ Schmidt (2005), p. 1237.
} 
La igualdad entre hombres y mujeres en el matrimonio debe analizarse desde dos puntos de vista:

i) en cuanto a los derechos y obligaciones entre los cónyuges de carácter personal, regulados en los artículos 131, 133 y 136 del Código Civil, y respecto de los efectos patrimoniales entre ellos, es decir, los regímenes patrimoniales, alimentos y compensación económica, y

ii) respecto de los derechos y obligaciones establecidos entre el padre o madre en la regulación de las relaciones paterno-filiales, es decir, en cuanto al cuidado personal de sus hijos, el régimen comunicacional y la patria potestad.

En primer lugar, respecto a las relaciones patrimoniales entre los cónyuges, mediante el DL N 328 de 1928 se inicia una tendencia ampliatoria de los derechos civiles de la mujer. Principalmente, se otorgó a las madres el derecho a ejercer la patria potestad sobre los hijos que tuvieran a su cargo, en caso de ausencia del padre, y a las mujeres divorciadas por culpa del marido, también respecto al régimen de bienes, se incorpora la posibilidad de pactar en las capitulaciones la separación de bienes y se considera a la mujeres separadas de bienes para la administración de los bienes producto de su trabajo ${ }^{58}$.

28 La tendencia continúa a fines de la década de 1980. Como lo señala Carmen Domínguez.

"la incapacidad relativa de la mujer casada en sociedad conyugal fue derogada al establecerse su plena capacidad por la Ley 18.802 de 1989 normativa que, sumada a los anteriores DL 328 de 1928, Ley 5.521 de 1934, Ley 10.271 de 1952, vino a atenuar considerablemente las facultades de administración del marido en el régimen de sociedad conyugal al establecer numerosas limitaciones en su actuar desde que requiere, para la celebración de los actos más importantes de disposición de los bienes comunes o propios de la mujer, de su autorización" 59 .

Sin embargo, en el régimen de sociedad conyugal, todavía encontramos algunas normas que discriminan a la mujer, como las referentes a la administración de los bienes sociales y los propios de la mujer por parte del marido (especialmente los arts. 1749 y 1750 del $C C$ ) ${ }^{60}$.

${ }^{58}$ Cfr. Giordano (2010), pp. 97-113.

${ }^{59}$ Domínguez (2005), p. 208.

${ }^{60}$ Es necesario considerar el acuerdo de solución pacífica alcanzado entre Sonia Arce Esparza con Chile, el 18 de octubre de 2005, caso $\mathrm{N}^{\circ} 12.433$, que dispone en la cláusula primera: "Primero: Garantías de no repetición: a. Derogación de las normas que establecen 
No observamos diferencias en el derecho de alimentos ni en la compensación económica, en ambos se refiere al "cónyuge", por lo que el ejercicio del derecho quedará subordinado a la prueba en juicio del estado de necesidad en los alimentos o de los requisitos de procedencia de la compensación económica.

En cuanto a los derechos y deberes de carácter personal entre los cónyuges, el Código Civil también establecía importantes diferencias entre ellos. Así, para Enrique Rossel:

“estas obligaciones y derechos están reglamentados en el Título VI del Libro I y admiten una clasificación que se formula atendiendo a si la vinculación jurídica genera iguales efectos para ambas partes o sólo para una de ellas: desde este punto de vista, son obligaciones comunes, o sea, comprometen por igual a ambos cónyuges, la fidelidad, el socorro y la asistencia, y son deberes especiales que afectan o al marido o a la mujer, la protección, la obediencia, el derecho de la mujer a ser recibida en la casa del marido y la convivencia" ${ }^{61}$.

En este sentido, la ley $\mathrm{N}^{\circ} 19.335$, de 23 de septiembre de 1994, modificó los efectos personales a fin de regular en forma igualitaria las obligaciones y derechos de carácter personal entre los cónyuges. Según Hernán Corral:

"la ley ha querido eliminar algunas diferencias que, aunque de poco relieve, se estimaron contrarias al principio de igualdad entre varones y mujeres. Ello se da principalmente respecto de los deberes de fidelidad y de socorro. Se aprovecha la oportunidad, también para ajustar otras normas de menor trascendencia al mismo principio igualitario" ${ }^{2}$.

En segundo lugar, en las relaciones paterno-filiales también existía una importante diferencia: el cuidado personal de los hijos. Cuando los

la discriminación de las mujeres en el régimen de sociedad conyugal. Para poner término a la discriminación legal implícita en el actual régimen de sociedad conyugal en Chile, y que ha motivado el inicio de este caso, el Estado de Chile se compromete a dotar -en forma inmediata- de la urgencia que se estime adecuada a la tramitación legislativa del proyecto de ley que modifica el Código Civil y leyes complementarias en materia de sociedad conyugal o comunidad de gananciales -en los términos de redacción en los que se encuentra-, otorgando a la mujer y al marido iguales derechos y obligaciones (Boletin, N $^{\circ}$ 1707-18)". Disponible en www.leychile.cl/Navegar?idNorma=270873. [Fecha de consulta: 20 de septiembre de 2014].

${ }^{61}$ Rossel (1958), p. 105.

${ }^{62}$ Corral (2007), p. 25. 
padres vivían separados, le correspondía a la madre (ex art. 225 del $C C$ ) y la patria potestad al padre. Dicha situación se mantuvo, con pequeñas modificaciones, hasta la entrada en vigencia de la ley $\mathrm{N}^{\circ} 20.680$, de 21 de junio de 2013, que deja en situación de plena igualdad a los padres ${ }^{63}$.

Esta ley moderniza los efectos de la filiación ajustándolos a los principios que rigen al moderno Derecho de Familia, principalmente el interés superior del niño, la igualdad parental y la autonomía de la voluntad.

Es así como el legislador privilegia los acuerdos de los padres en materia de cuidado personal, relación directa y regular y patria potestad, los que deben cumplir con las formalidades legales analizadas, pero que a diferencia de las pensiones de alimentos no requieren aprobación judicial, salvo los casos del acuerdo completo y suficiente.

En caso de tener que recurrir a la justicia, la única causal existente es el interés superior del niño, principio rector en materia de familia, que supone que el juez de familia debe atribuir el cuidado personal de los niños al padre que garantice de mejor forma el bienestar de sus hijos, procurando el pleno respeto de sus derechos fundamentales.

Por último, los padres se encuentran en igualdad de condiciones en materia de efectos de la filiación, con lo que se ajusta nuestro derecho de familia a las normas constitucionales y a los tratados internacionales 30 sobre derechos humanos.

\section{b) Principio de igualdad de los hijos}

El respeto por el principio de igualdad de los hijos se consagra en la Convención sobre los Derechos de los Niños, sí se puede ver en su artículo $2^{\circ}$ :

"los Estados Partes respetarán los derechos enunciados en la presente Convención y asegurarán su aplicación a cada niño sujeto a su jurisdicción, sin distinción alguna, independientemente de la raza, el color, el sexo, el idioma, la religión, la opinión política o de otra índole, el origen nacional, étnico o social, la posición económica, los impedimentos físicos, el nacimiento o cualquier otra condición del niño, de sus padres o de sus representantes legales".

No obstante, nuestra legislación discriminaba a los hijos dependiendo si nacían dentro del matrimonio o no. Así, de acuerdo con el Código Civil de Andrés Bello:

"se reconocían diferentes tipos de filiación, tales como la filiación legítima, filiación ilegítima y, dentro de ésta, la filiación natural

${ }^{63}$ Cfr. Lepin (2014a), pp. 139-170. 
respecto de aquel que había recibido reconocimiento voluntario del padre o madre, o respecto de aquel que había obtenido tal reconocimiento mediante una sentencia judicial, en juicio contradictorio, seguido contra el padre o la madre respectivos. Igualmente, existían los hijos simplemente ilegítimos reconocidos para el solo efecto de pedir alimentos" ${ }^{64}$.

Lo que se mantuvo hasta el año 1998, fecha en que la ley $\mathrm{N}^{\circ} 19.585$ hacer efectivo este principio derogó muchas disposiciones que regulaban el establecimiento y determinación de la filiación y de alguno de sus efectos. Así, por ejemplo, el artículo 33 del Código Civil, con la nueva redacción señala: "la ley considera iguales a todos los hijos".

Las principales consecuencias derivadas de la arbitraria discriminación estaban determinadas por la nula posibilidad de investigación de la paternidad y los efectos de la filiación principalmente en materia de alimentos y derechos sucesorios.

En cuanto a la investigación de la paternidad, el Código Civil-siguiendo al Código francés- prohibía la investigación de la paternidad, situación que se mantuvo hasta la entrada en vigencia de la citada ley $\mathrm{N}^{\circ} 19.585^{65}$. Dicha ley permite, a través de las acciones de filiación (art. 195 y ss. del $C C$ ), conocer la verdad biológica y hacer efectivo el derecho a la identidad de los hijos consagrado en los artículos 7 y 8 de la Convención de Derechos del Niño.

En cuanto a los alimentos, el Código Civil permitía a los hijos de filiación legítima (nacidos durante el matrimonio de sus padres) obtener de ellos alimentos congruos (que habilitan para subsistir de acuerdo con su posición social) y a los hijos naturales solo alimentos necesarios (lo básico para subsistir). Lo que fue de igual manera eliminado.

Por último, respecto a los derechos hereditarios, el Código Civil hasta la entrada en vigencia de la ley $\mathrm{N}^{\circ} 19.585$, establecía los derechos sucesorios de los hijos según el tipo de filiación, lo que según dijimos fue eliminado por la ley $\mathrm{N}^{\circ} 19.585$. Los hijos naturales recibían, por regla general la mitad de lo que recibían los hijos legítimos.

${ }^{64}$ Álvarez (1998), p. 35.

${ }^{65}$ Resulta interesante la sentencia del caso Godoy Saldaña y otros con Director Regional del Servicio de Registro Civil e Identificación Región del Bío Bío (2014), que rechaza un recurso de protección, y que entre otras cosas señala: "que de lo anteriormente consignado fluye que hasta la entrada en vigor de la Ley $\mathrm{N}^{\circ} 19.585$ aparecía como una facultad de los padres el reconocer a sus hijos nacidos fuera del matrimonio, a partir de la entrada en vigencia de esta ley, hoy constituye un derecho, pues, a los padres se les impuso el deber de reconocer a sus hijos. 
En este sentido, Andrea Muñoz considera:

"es menester tener presente que al introducir esta importante reforma, la nueva ley no hace sino concluir, como dice el mensaje del proyecto: ...'una larga e interesante evolución habida en el derecho sucesorio chileno, en virtud de la cual los hijos concebidos fuera del matrimonio han accedido a posiciones más equitativas, aunque aún discriminatorias'. Debemos recordar que en la legislación ahora vigente, los hijos naturales eran legitimarios, esto es herederos forzosos, y concurrían en el primer orden de sucesión con los descendientes legítimos, correspondiéndoles, sin embargo, la mitad de la cuota que llevaban los legítimos y con la limitación que la parte que les correspondiere, en concurrencia con los hijos legítimos, en ningún caso podía exceder, en conjunto, de una cuarta parte de la herencia o de una cuarta parte de la mitad legitimaria, en su caso (art. 988 del C. Civil, antes de la reforma)"66.

En la actualidad, entonces, los hijos sin distinción concurren en el primer orden de sucesión, estos excluyen a todos los otros herederos, a menos que hubiere también cónyuge sobreviviente, caso en el cual este concurrirá con aquellos (art. $988 \mathrm{del} C C$ ).

Por último, con la ley $\mathrm{N}^{\circ} 19.620$ se eliminan también las diferencias con respecto a los adoptados, así se evidencia en su artículo $1^{\circ}$ inciso $2^{\circ}$ :

"la adopción confiere al adoptado el estado civil de hijo respecto del o los adoptantes en los casos y con los requisitos que la presente ley establece".

En consecuencia, la totalidad de las discriminaciones en materia de filiación han sido eliminadas, en su mayoría por la ley $\mathrm{N}^{\circ} 19.585$ y la ley $\mathrm{N}^{\circ} 19.620$, equiparando los derechos a todos los hijos de filiación determinada, nacidos dentro o fuera del matrimonio, ya sea por filiación biológica, por técnicas de reproducción humana asistida o por adopción.

\section{PRINCIPIO DE PROTECCIÓN DEL MÁS DÉBIL}

Con la tendencia igualatoria de derechos, surge la necesidad de proteger a las personas que se encuentran en una situación de especial indefensión

${ }^{66}$ MuÑoz (1999), p. 132. 
o desamparo, que haga imperiosa la intervención del Estado a través de sus órganos, especialmente, por la judicatura de familia.

La debilidad puede tener su origen en distintas situaciones, como la violencia intrafamiliar, la vulneración de los derechos de los niños o por razones económicas, y puede afectar a uno de los cónyuges, a los niños, incapaces o ancianos.

Así lo consagran los tratados internacionales sobre derechos humanos, por ejemplo la Declaración Universal de los Derechos Humanos, que en su artículo $25 \mathrm{~N}^{\circ} 2$, señala:

"La maternidad y la infancia tienen derecho a cuidados y asistencia especiales. Todos los niños, nacidos de matrimonio o fuera de matrimonio, tienen derecho a igual protección social”67.

El Derecho de Familia tiene una especial función protectora de los derechos de quienes resultan ser los más débiles en las relaciones de familia. Nos referimos a la protección de los derechos de los niños y del cónyuge más débil, según se analizará a continuación.

\section{a) Principio del interés superior del niño}

Este principio, alcanza reconocimiento internacional con la Convención sobre los Derechos de los Niños, en su preámbulo se puede leer:

"Considerando que el niño debe estar plenamente preparado para una vida independiente en sociedad y ser educado en el espíritu de los ideales proclamados en la Carta de las Naciones Unidas y,

${ }^{67}$ El Pacto Internacional de Derechos Civiles y Políticos, en su artículo $24 \mathrm{~N}^{\circ} 1$, prescribe: "Todo niño tiene derecho, sin discriminación alguna por motivos de raza, color, sexo, idioma, religión, origen nacional o social, posición económica o nacimiento, a las medidas de protección que su condición de menor requiere, tanto por parte de su familia como de la sociedad y del Estado".

El Pacto internacional de derechos económicos, sociales y culturales, en el artículo 10.3 dispone: "Se deben adoptar medidas especiales de protección y asistencia en favor de todos los niños y adolescentes, sin discriminación alguna por razón de filiación o cualquier otra condición. Debe protegerse a los niños y adolescentes contra la explotación económica y social. Su empleo en trabajos nocivos para su moral y salud, o en los cuales peligre su vida o se corra el riesgo de perjudicar su desarrollo normal, será sancionado por la ley. Los Estados deben establecer también límites de edad por debajo de los cuales quede prohibido y sancionado por la ley el empleo a sueldo de mano de obra infantil".

El Pacto de San José de Costa Rica, en su artículo 19 señala: “Todo niño tiene derecho a las medidas de protección que su condición de menor requieren por parte de su familia, de la sociedad y del Estado". 
en particular, en un espíritu de paz, dignidad, tolerancia, libertad, igualdad y solidaridad ... Teniendo presente que, como se indica en la Declaración de los Derechos del Niño, 'el niño, por su falta de madurez física y mental, necesita protección y cuidados especiales, incluso la debida protección legal, tanto antes como después del nacimiento"”.

$\mathrm{El}$ artículo $3^{\circ}$ lo incorpora de forma expresa, al señalar:

"1. En todas las medidas concernientes a los niños que tomen las instituciones públicas o privadas de bienestar social, los tribunales, las autoridades administrativas o los órganos legislativos, una consideración primordial a que se atenderá será el interés superior del niño.

2. Los Estados Partes se comprometen a asegurar al niño la protección y el cuidado que sean necesarios para su bienestar, teniendo en cuenta los derechos y deberes de sus padres, tutores $\mathrm{u}$ otras personas responsables de él ante la ley y, con ese fin, tomarán todas las medidas legislativas y administrativas adecuadas.

3. Los Estados Partes se asegurarán de que las instituciones, servicios y establecimientos encargados del cuidado o la protección de los niños cumplan las normas establecidas por las autoridades competentes, especialmente en materia de seguridad, sanidad, número y competencia de su personal, así como en relación con la existencia de una supervisión adecuada”.

No obstante, es posible leer en la observación general $\mathrm{N}^{\circ} 14$ del Comité de Derechos del Niño:

"el interés superior del niño no es un concepto nuevo. En efecto, es anterior a la Convención y ya se consagraba en la Declaración de los Derechos del Niño, de 1959 (párrafo 2) y la Convención sobre la eliminación de todas las formas de discriminación contra la mujer (artículos 5 b) y 16, párrafo 1 d), así como en instrumentos regionales y numerosas normas jurídicas nacionales e internacionales"68.

${ }^{68}$ Comité de Derechos del Niño, Naciones Unidas. Observación general Nº 14 (2013), sobre el derecho del niño a que su interés superior sea una consideración primordial. 
De esta forma, el interés superior se transforma en el principio rector en materia de familia ${ }^{69}$, que de acuerdo con el artículo 222 del Código Civil consiste en:

"la mayor realización espiritual y material posible, y lo guiarán en el ejercicio de los derechos esenciales que emanan de la naturaleza humana de modo conforme a la evolución de sus facultades".

La ley $\mathrm{N}^{\circ} 19.968$, que crea los Tribunales de Familia, señala en su artículo 16 inciso $2^{\circ}$ :

“[el] interés superior del niño, niña o adolescente, es el principio rector que el juez de familia debe tener siempre como consideración principal en la resolución del asunto sometido a su conocimiento".

La ley $\mathrm{N}^{\mathrm{O}}$ 19.620, que dicta Normas sobre Adopción de Menores, lo establece explícitamente, en el artículo $1^{\circ}$ : "la adopción tiene por objeto velar por el interés del adoptado", principio que reitera en sus artículos $3^{\circ}$ y 15 inciso $3^{\circ}$.

En la NLMC se consagra como uno de sus principios informadores, en su artículo $3^{\circ}$, según el cual: "las materias reguladas por esta ley deberán ser resueltas cuidando proteger siempre el interés superior de los hijos...”. Además, reiteran la misma idea en los artículos 27 inciso $2^{\circ}, 36$ y 85 inciso $2^{\circ}$.

Este principio encabeza el título Ix del Código Civil: "De los derechos y obligaciones entre los padres y los hijos". Pero se encuentra presente en todo nuestro ordenamiento jurídico ${ }^{70}$.

${ }^{69}$ En este sentido, la sentencia López Allende con Atala Riffo (2004), señala: "el ejercicio de las potestades y la ejecución de los deberes que comprende la tuición debe llevarse a cabo en el marco del principio básico que orienta en la materia el ordenamiento jurídico nacional y que recoge, entre otros preceptos, el inciso segundo del artículo 222 del mismo Código Civil al declarar que 'la preocupación fundamental de los padres es el interés superior del hijo...' y al que responden igualmente las disposiciones de los párrafos primeros de los artículos $3^{\circ}$ y $9^{\circ}$ de la "Convención Internacional sobre Derechos del Niño" ratificada por Chile, según las cuales en todas las medidas que le conciernan, es primordial atender al interés superior del niño sobre otras consideraciones y derechos relativos a sus progenitores y que puedan hacer necesario separarlo de los padres". Agrega: "los tribunales están obligados a considerar ese principio esencial al resolver los asuntos relacionados con derechos y obligaciones de padres e hijos, tanto porque esa noción representa el espíritu general de la legislación en la materia, cuanto porque así lo manda el legislador”. En el mismo sentido, la sentencia Meza Saavedra con de la Rivera Araya (2010).

${ }^{70}$ Es un principio inspirador de diversas disposiciones del Código Civil, como los artículos 222 inciso $1^{\circ}, 225,225-2,226,229,234,240,242,244,245,268$ y 272. 
La sentencia de 7 de octubre de 2004, de la Corte de Apelaciones de Santiago, en la causa rol 7166-2003, considera:

"que el interés del menor constituye un concepto jurídico indeterminado, de contornos imprecisos y de profusa utilización en el derecho comparado. No obstante, puede afirmarse que alude a asegurar al menor el ejercicio y protección de sus derechos fundamentales; y a posibilitar la mayor suma de ventajas, en todos los aspectos de su vida, en perspectiva de su autonomía y orientado a asegurar el libre desarrollo de su personalidad; concepto, en todo caso, cuyos contornos deben delimitarse en concreto, en cada caso"71.

Para Miguel Cillero, el interés superior del hijo "es la plena satisfacción de sus derechos. El contenido del principio son los propios derechos; interés y derecho en este caso se identifican" ${ }^{\prime 2}$.

En un sentido similar, para Encarna Roca:

"el interés del menor se identifica con la protección de aquellos derechos que el ordenamiento jurídico atribuye, con la categoría de fundamentales a las personas. Por ello, la regulación que implemente este principio, las resoluciones judiciales que deban decidir en relación con problemas planteados por menores, no se encuentra con un concepto vacío, puesto que su contenido consiste en asegurar la efectividad de unos derechos a unas personas que por sus condiciones de madurez, no pueden actuar por sí mismas, de forma independiente para reclamar su efectividad"73.

${ }^{71}$ Varela Walker con Montes Larraín (2003).

${ }^{72}$ Cillero (2007), p. 134. En un sentido similar, la sentencia Massis Nazar con Sánchez Luengo (2010), Considerando $10^{\circ}$, que establece: "en estas materias debe tenerse siempre en consideración el interés del niño, como dispone el artículo 16 de la Ley de Tribunales de Familia. Aun cuando constituye un concepto indeterminado, cuyo alcance se aprecia cuando es aplicado al caso concreto, puede afirmarse que consiste en el pleno respeto de los derechos esenciales del niño, niña o adolescente, para procurar el cabal ejercicio y protección de sus derechos esenciales. El interés superior del niño aporta, también, en el ámbito de la interpretación, al constituir una norma de resolución de conflictos jurídicos, permitiendo decidir así situaciones de colisión de derechos, según su contenido y la ponderación de los que se encuentran en pugna. En este sentido, cobran especial interés los efectos que el referido principio produce en el marco de las relaciones parentales, en las que, por un lado, se encuentra el derecho y responsabilidad de los padres de cuidar y educar a los hijos y, por otro, la protección y desarrollo de la autonomía del niño en el ejercicio de sus derechos, lo que limita las facultades o roles de los padres, precisamente por interés superior de los menores, en aras de la satisfacción integral de sus derechos".

${ }^{73}$ Roca (1999), p. 220. 
La noción de "interés" resulta útil para superar el problema de la capacidad de los niños para ser titulares y ejercer sus derechos. Así lo expresa Encarna Roca, para quien

"a partir de aquí se va a manifestar una nueva preocupación: ¿cuál es el origen de estos derechos? Alston y Parker centran el debate en torno a dos grandes grupos de autores: aquellos que opinan que la base de cualquier regulación fundada en derechos es la voluntad y aquellos que ponen el acento en el interés. La primera de estas teorías no es útil, según estos autores, para legitimar a unas personas que por su edad y condiciones de madurez, no pueden formular una voluntad 'plausible'. En cambio, la teoría del interés permitiría protegerlos a través de la utilización de la teoría de la titularidad de estos mismos derechos"74.

Por tanto, este interés está unido al ejercicio de sus derechos fundamentales, los que deben ser respetados en las distintas etapas de desarrollo de la niñez.

De esta forma, el interés superior inspira toda la normativa sobre las relaciones paterno-filiales, pero también es fuente de orientación para la interpretación de las normas y para resolver conflictos de normas o colisión de derechos.

En este sentido, Miguel Cillero cree que este principio tiene una triple función:

"es una garantía, ya que toda decisión que concierna al niño, debe considerar primordialmente sus derechos; es de una gran amplitud ya que no solo obliga al legislador sino también a todas las autoridades e instituciones públicas y privadas y a los padres; también es una norma de interpretación y/o de resolución de conflictos jurídicos; finalmente es una orientación o directriz política para la formulación de políticas públicas para la infancia, permitiendo orientar las actuaciones públicas hacia el desarrollo armónico de los derechos de todas las personas, niños y adultos, contribuyendo, sin dudas, al perfeccionamiento de la vida democrática" 75 .

De este modo, para Maricruz Gómez de la Torre, el interés del niño en materia de filiación, llevado a la práctica, consiste en ${ }^{76}$ :

\footnotetext{
${ }^{74}$ Roca (1999), p. 214.

${ }^{75}$ Cillero (2007), p. 141.

${ }^{76}$ Gómez de la Torre (2007), p. 47.
} 
- Permitirle la indagación de su filiación (mediante las acciones de filiación), cuando esta no esté determinada, pues se vincula a su derecho a la identidad personal, uno de cuyos atributos esenciales es tener un nombre y conocer a sus padres.

- Garantizarle los derechos que surgen de su calidad de persona humana, los que deben ser respetados en el ejercicio de la autoridad de los padres.

- Permitirle manifestar su opinión y tomarla en cuenta de acuerdo con su edad y grado de madurez, en todas las instancias judiciales o extrajudiciales en que tenga interés el niño.

- Permitirle permanecer con el padre que mejor asegure su bienestar físico y espiritual y, al mismo tiempo, facilitar su vinculación con el otro padre, en caso de separación, nulidad o divorcio de los padres.

- Velar porque se proteja su interés, para lo cual debe ser escuchado y tomado en cuenta de acuerdo con su edad y grado de madurez, en caso de separación, nulidad o divorcio, tanto en los acuerdos regulatorios como en la mediación, en la que los cónyuges decidan sobre el cuidado personal, régimen comunicacional, alimentos y patria potestad de los hijos.

Un avance en materia de cuidado personal y relación directa y regular será el contenido que la jurisprudencia pueda dar a los criterios establecidos en el artículo 225-2 del Código Civil ${ }^{7}$, para el establecimiento y

77 Código Civil artículo 225-2: "En el establecimiento del régimen y ejercicio del cuidado personal, se considerarán y ponderarán conjuntamente los siguientes criterios y circunstancias:

a) La vinculación afectiva entre el hijo y sus padres, y demás personas de su entorno familiar.

b) La aptitud de los padres para garantizar el bienestar del hijo y la posibilidad de procurarle un entorno adecuado, según su edad.

c) La contribución a la mantención del hijo mientras estuvo bajo el cuidado personal del otro padre, pudiendo hacerlo.

d) La actitud de cada uno de los padres para cooperar con el otro, a fin de asegurar la máxima estabilidad al hijo y garantizar la relación directa y regular, para lo cual considerará especialmente lo dispuesto en el inciso quinto del artículo 229.

e) La dedicación efectiva que cada uno de los padres procuraba al hijo antes de la separación y, especialmente, la que pueda seguir desarrollando de acuerdo con sus posibilidades.

f) La opinión expresada por el hijo.

g) El resultado de los informes periciales que se haya ordenado practicar.

h) Los acuerdos de los padres antes y durante el respectivo juicio.

i) El domicilio de los padres.

j) Cualquier otro antecedente que sea relevante atendido el interés superior del hijo". 
ejercicio del régimen de cuidado personal y para determinar el régimen de relación directa y regular, en el artículo 229 del Código $\mathrm{Civil}^{8}$.

Indudablemente el interés superior se transforma en un medio para hacer efectivos otros derechos o principios derivados de materias en que participen niñas, niños o adolescentes ${ }^{79}$. Transformándose en un principio general de la legislación ${ }^{80}$, o como señala Miguel Cillero, la Convención otorga al interés superior del niño un carácter fundamental, con un rol jurídico definido, que se proyecta no solo al ordenamiento jurídico sino, también, hacia las instituciones públicas y privadas de bienestar social. Esto ha sido reconocido por el Comité de los Derechos del Niño establecido en la propia Convención, para el cual el interés superior del niño es uno de los principios generales de la Convención, llegando a considerarlo como "principio rector-guía" de ella ${ }^{81}$.

\section{b) Principio de protección del cónyuge más débil}

Los instrumentos internacionales sobre derechos humanos, ya citados, introducen en forma expresa el derecho a la igualdad, la prohibición de discriminar y la obligación imperativa de proteger los derechos fundamentales contra cualquier tipo de discriminación: artículo $2^{\circ}$ de la Declaración Americana de Derechos y Deberes del Hombre; artículo 1.1 y 24 de la Convención Americana sobre Derechos Humanos; artículos 2 y 7 de la Declaración Universal de Derechos Humanos; artículo 2 del Pacto Internacional de Derechos Económicos, Sociales y Culturales, y artículos 2 y 26 del Pacto Internacional de Derechos Civiles y Políticos.

${ }^{78}$ Código Civil artículo 229, inciso $3^{\circ}$ : "Para la determinación de este régimen, los padres, o el juez en su caso, fomentarán una relación sana y cercana entre el padre o madre que no ejerce el cuidado personal y su hijo, velando por el interés superior de este último, su derecho a ser oído y la evolución de sus facultades, y considerando especialmente:

a) La edad del hijo.

b) La vinculación afectiva entre el hijo y su padre o madre, según corresponda, y la relación con sus parientes cercanos.

c) El régimen de cuidado personal del hijo que se haya acordado o determinado.

d) Cualquier otro elemento de relevancia en consideración al interés superior del hijo".

${ }^{79}$ Así, por ejemplo, en materia de filiación: Velásquez Basaez con Zimmert Michel (2014). En materia de pensiones de alimentos: J.V.R. con L.A.S.V. (2014) y J.V.R. con L.A.S.V. (2014). En la adopción: Román Hartard y otro con [no se consigna] (2014). En la Ley de Matrimonio Civil: Vargas Aguirre con Delgado Adaros (2005); Calderón Barraza con Munizaga Castro (2006) y Espina Brisso con Varela Lagos (2010).

${ }^{80}$ Cfr. Comité de Derechos del Niño, Naciones Unidas. Observación general N ${ }^{\circ} 14$ (2013) sobre el derecho del niño a que su interés superior sea una consideración primordial y observación general $\mathrm{N}^{\circ} 12$ (2009) El Derecho del Niño a ser escuchado.

${ }^{81}$ Cillero (2007), pp. 126-127. 
El principio de igualdad, garantizado por la Constitución y por los tratados internacionales ratificados por Chile y que se encuentran vigentes, obliga al legislador a crear los mecanismos jurídicos orientados a solucionar el problema de la desigualdad entre hombres y mujeres ${ }^{82}$.

Por su parte, la ley $\mathrm{N}^{\circ} 19.947$ que entró en vigencia el 18 de noviembre de 2004, incorporó por primera vez en la legislación chilena el divorcio vincular. Con ello surgió, desde la presentación del proyecto de ley en el año 1995 y durante toda su tramitación, la preocupación por proteger al cónyuge que al momento de la ruptura queda en una precaria situación económica. En un primer momento, esta preocupación se expresó a través de la idea de la exigencia de establecer relaciones equitativas entre los cónyuges hacia el futuro y procurar aminorar el daño que pudo causar la ruptura, en los casos de divorcio y en especial al presentar un convenio regulador de las relaciones familiares ${ }^{83}$.

Regular relaciones equitativas entre los cónyuges hacia el futuro (aparece en el primer proyecto legislativo presentado en el año 1995, en el artículo 63 , y en la ley $\mathrm{N}^{\circ} 19.947$ se encuentra consagrado en los artículos $3^{\circ}, 27 \mathrm{y}$ $55)$, se vincula, por cierto, con las normas constitucionales e internacionales, que prohíben la discriminación, especialmente contra la mujer.

De acuerdo con las actas de la NLMC, en el segundo trámite constitu40 cional, se fortalece la idea de proteger al cónyuge más débil, mediante la incorporación del derecho de compensación económica y de la denominada "cláusula de dureza", que permite al juez rechazar el divorcio en caso de incumplimiento por parte del cónyuge demandante de la obligación alimenticia respecto del otro cónyuge o los hijos ${ }^{84}$.

Otra medida tendiente a asegurar esa protección del cónyuge más débil es el control que realiza el juez al aprobar un acuerdo en sede de separación o divorcio, calificándolo de completo y suficiente (arts. 21, 27 y 55 de la NLMC).

El principio de protección del cónyuge más débil, como se ha señalado, fue reconocido e incorporado expresamente por la NLMC en el artículo $3^{\circ}$. Por tanto, solo sería aplicable a las materias reguladas por ésta, es decir, a la separación, nulidad o divorcio ${ }^{85}$.

${ }^{82}$ En este sentido, Veloso (2006), p. 176.

${ }^{83}$ LePIN (2012), pp. 4-5.

${ }^{84}$ Op. cit., p. 5.

${ }^{85}$ No obstante, esta afirmación resulta discutible, ya que algunos autores han señalado que "no se trata de un principio creado por la Ley de Matrimonio Civil, pues ya estaba consagrado en el Código Civil, por ejemplo, en las normas relativas a los bienes familiares (artículos 141 a 149); en las disposiciones de la sociedad conyugal destinadas a proteger a la mujer (especialmente en lo que se refiere a las limitaciones a la administración ordinaria de la sociedad conyugal, establecidas en el artículo 1749, en las normas que favorecen 
De esta manera, se puede concluir que es un mandato dirigido al juez de familia llamado a resolver el conflicto, para proteger al más débil en la relación familiar. Así, el inciso $1^{\circ}$ del artículo $3^{\circ}$ de la NLMC dispone:

"las materias de familia reguladas por esta ley deberán ser resueltas cuidando proteger siempre el interés superior de los hijos y del cónyuge más débil" ${ }^{86}$.

La protección al cónyuge más débil, consagrada en el citado artículo $3^{\circ}$ de la NLMC, presenta una serie de interrogantes, tanto en cuanto su contenido como con respecto a su alcance.

La ley no define qué se entiende por cónyuge más débil, sin embargo, Pablo Rodríguez ha sostenido que podemos entender por tal "al que se encuentre en una posición económica, psíquica, emocional o fisiológica desmedrada" $"$.

En un sentido similar, Rodrigo Barcia señala:

“pareciera ser que la referencia al 'cónyuge débil' no debe entenderse con relación al otro cónyuge por cuanto ello siempre supondría que uno de los cónyuges está en una situación de debilidad. Así, la debilidad del cónyuge debe ser evidente y configurarse por una causa objetiva, como podría ser una enfermedad" 88 .

Para José Guerrero, en cambio, es fácil constatar que la NLMC no define qué debe entenderse por cónyuge más débil, sin embargo, de la discusión parlamentaria no cabe duda de que se legisló pensando en proteger a aquel cónyuge que se encontrara, con ocasión de la ruptura matrimonial, en un posición de desmedro económico frente al otro, para comenzar su vida de forma separada e independiente ${ }^{89}$.

Estimamos que la definición dada por Pablo Rodríguez es demasiado amplia, abarcando aspectos que no son parte integrante del menoscabo

a la mujer para el pago de las recompensas que se le adeuden, al liquidarse la sociedad conyugal, según lo dispuesto en el artículo 1773, y en el beneficio de emolumento que opera a favor de la mujer, consagrado en el artículo 1777); y en aquellas que se consagran en el crédito de participación en los gananciales, al término de dicho régimen (artículos 1792-20 al 1792-26). Lo mismo ocurre con las normas de alimentos, tanto del Código Civil (artículos 321 al 337) como de la Ley 14.908 sobre Abandono de Familia y Pago de Pensiones Alimenticias", Orrego (2004), n. al pie de p., pp. 20-21.

${ }^{86}$ Biblioteca del Congreso Nacional (2004), pp. 447-448.

${ }^{87}$ Rodríguez (2004), s/p.

${ }^{88}$ Barcia (2011), p. 37.

${ }^{89}$ Guerrero (2008), p. 102 y Hübner (2005), pp. 26-27. 
que pretende reparar el derecho a compensación económica. A nuestro parecer, la noción de cónyuge más débil solo se restringe al desmedro económico.

En conclusión, la ley entiende que uno de los cónyuges (más débil) queda en una situación de desmedro económico frente al otro cónyuge (más fuerte) al momento del término del matrimonio, ya sea por divorcio o nulidad, que se traduce en sus escasas posibilidades de negociación ${ }^{90}$.

En consecuencia, la protección del cónyuge más débil "económicamente" es una manifestación de un principio de carácter general, la equidad, que en la legislación chilena faculta al juez para corregir la desigualdad entre los cónyuges proveniente del menoscabo económico que la ruptura puede generar en un cónyuge, producto de no haber realizado actividad remunerada o lucrativa durante el matrimonio.

Este principio se concreta en la NLMC principalmente en los casos de compensación económica. En primer lugar, al determinar la cuantía, debe fijar el monto en una unidad reajustable (en forma similar a las pensiones de alimentos), y fijar seguridades para el pago (mediante alguna caución real o personal, u otro mecanismo que garantice el pago de la compensación). También el juez de familia debe informar sobre el derecho a compensación económica a las partes en la audiencia preparatoria de juicio, según consagra el artículo 64 de la NLMC. En caso de incumplimiento de este deber, procede el recurso casación en la forma (art. $768 \mathrm{~N}^{\circ} 9$ del $C P C$ ), por tratarse de un trámite considerado esencial ${ }^{91}$.

Relacionado con lo anterior, se encuentra la oportunidad para demandar compensación económica. Según prescribe el artículo 64 de la NLMC, solo se puede hacer en la demanda, escrito complementario de la demanda o en la demanda reconvencional. Sin embargo, dado este deber de informar, si el cónyuge más débil no presentó su acción en dicha oportunidad, el juez puede autorizarlo (basado en la protección del cónyuge más débil), a que presente su demanda en la misma audiencia preparatoria, situación que en estricto rigor no procede, ya que precluyó el derecho ${ }^{92}$.

Para nuestra jurisprudencia, la compensación económica es la principal expresión del principio de protección al cónyuge más débil ${ }^{93}$.

${ }^{90}$ LePIN (2013b), p. 519.

${ }^{91}$ Así lo ha resuelto la Corte de Apelaciones de Valdivia: sentencia Álvarez Quena con Raimilla Espinoza (2007); la Corte de Apelaciones de Talca: sentencia Flores Sepúlveda con Mora Mora (2006). La Corte Suprema ha decidido también invalidar de oficio la sentencia por incumplimiento del deber de informar, en la sentencia Durán Espinoza con Miranda Bustos (2011).

${ }^{92}$ LePin (2013b), p. 530.

${ }^{93}$ Henzi con Plaza Reveco (2011); von Elgott con Baumgartner (2012) y González Navarro con Herrera Valencia (2012). 
Otro de los mecanismos de protección del cónyuge más débil es la denominada por la doctrina como "cláusula de dureza", que permite al juez rechazar el divorcio por cese de convivencia solicitado unilateralmente, cuando a solicitud de la parte demandada, verifique que el demandante, durante el periodo de cese de convivencia, no dio cumplimiento, en forma reiterada, a su obligación de alimentos, respecto del cónyuge demandado y de los hijos comunes, pudiendo hacerlo (artículo 55 inciso $3^{\circ}$ de la NLMC $)^{94}$.

Por último, la NLMC considera la facultad del juez de calificar el convenio presentado por los cónyuges en los juicios de separación o divorcio, como completo y suficiente. Así, el acuerdo será completo si regula todas y cada una de las materias indicadas en el artículo 21 de la NLMC, es decir, las que tienen relación con las relaciones mutuas entre los cónyuges, a saber:

a) los alimentos que se deban ${ }^{95} \mathrm{y}$

b) las materias vinculadas al régimen de bienes del matrimonio, es decir, la liquidación de la sociedad conyugal o la determinación del crédito de participación, esto último en el régimen de participación en los gananciales.

El convenio debe regular, además, las materias respecto de los hijos comunes, que son:

a) el cuidado personal;

b) la pensión de alimentos y

c) el régimen comunicacional o de relación directa y regular del padre que no tiene la custodia de los hijos.

Según el artículo 55 inciso $2^{\circ}$ de la NLMC, se entenderá que el acuerdo es suficiente si resguarda el interés superior de los hijos, procura aminorar el menoscabo económico que pudo causar la ruptura y establece relaciones equitativas, hacia el futuro, entre los cónyuges cuyo divorcio se solicita.

${ }^{94}$ Así, lo ha resuelto la Corte Suprema, en sentencia Malebrán Castañeda con Corral Gallardo (2011), que señala: "que el inciso tercero del artículo 55 de la ley $\mathrm{N}^{\circ} 19.947$, previene que no se dará lugar al divorcio si el demandante durante el cese de la convivencia '...no ha dado cumplimiento, reiterado, a su obligación de alimentos respecto del cónyuge demandado y de los hijos comunes', la finalidad de la disposición, es sancionar la infracción a la obligación de socorro y el principio de protección al cónyuge más débil".

${ }^{95}$ Debemos entender las deudas por pensiones alimentarias devengadas, ya que en virtud de lo dispuesto por el artículo 60 de la NLMC, "el divorcio pone fin a las obligaciones y derechos de carácter patrimonial cuya titularidad y ejercicio se fundan en la existencia del matrimonio, como los derechos sucesorios recíprocos y el derecho de alimentos", en consecuencia, no se puede regular una pensión de alimentos para el ex cónyuge. 


\section{Autonomía de LA VOLUnTAD en el Derecho de Familia}

En un escenario donde se garantiza el pleno ejercicio de los derechos humanos de los ciudadanos, incluso en el ámbito familiar, donde priman el pleno ejercicio de la libertad y la igualdad entre los integrantes del grupo familiar, son estos los primeros llamados a resolver sus conflictos. Para Gustavo Bossert y Eduardo Zannoni:

"ha sido frecuente considerar que, como las relaciones jurídicas familiares escapan generalmente a la autonomía privada -o autonomía de la voluntad-, la teoría general del acto jurídico es extraña al derecho de familia. Se juzga que las relaciones familiares, y los derechos y deberes que tales relaciones determinan, no tienen por fuente la voluntad de los sujetos sino a la ley que, en cada caso, dispone los efectos de tales relaciones" ${ }^{\prime 96}$.

Luego, agregan:

"sin embargo, se ha sostenido que cuando la constitución de las relaciones familiares nace de la voluntad de las personas (la de los contrayentes en el matrimonio, la del progenitor que reconoce a un hijo, la de los adoptantes, etc.) se está frente a auténticos actos jurídicos que son la fuente de relaciones de familia" ${ }^{97}$.

Así, para Luis Díez-Picazo:

"el poder que se reconoce a la voluntad de las partes no es consecuencia de un desinterés o de un abandono de las situaciones reguladas por parte del legislador. Lejos de ello, nos parece que se trata simplemente de reconocer que los que están más cerca de los problemas pueden regularlos mejor que otros que, distanciados, sólo podrían formular un juicio demasiado abstracto" 98 .

De esta forma, con las profundas transformaciones del Derecho de Familia, el campo de aplicación de la autonomía privada ha tenido un avance sostenido en materias de familia. En este orden de ideas, el margen de autonomía de la voluntad de los cónyuges se amplía considerablemente,

${ }^{96}$ Bossert y Zannoni (2007), pp. 22-23.

${ }^{97}$ Op. cit., p. 23.

${ }^{98}$ Díez-Picazo (1989), p. 43. 
pues, por un lado, ya no están obligados a permanecer unidos para toda la vida, sino que, acreditando en juicio una de las causales de divorcio, ya sea por culpa o por cese efectivo de la convivencia, pueden poner término al vínculo conyugal. Por otro lado, en sede de separación y de divorcio se les permite a las partes regular sus relaciones mutuas y las concernientes a sus hijos, y eso sin considerar la conciliación y la mediación, como formas alternativas de resolver los conflictos de familia en sede judicial ${ }^{99}$.

De forma progresiva nuestro legislador ha facultado a los cónyuges para decidir una serie de materias relacionadas tanto con el matrimonio como con respecto de sus hijos comunes. Podemos mencionar, el convenio regulador, el reconocimiento de un hijo, la adopción, la promesa de matrimonio, las capitulaciones matrimoniales, la sustitución del régimen patrimonial del matrimonio, la liquidación de la sociedad conyugal, la determinación del crédito de participación en el régimen de participación en los gananciales, la asignación del cuidado personal y de la patria potestad, las transacciones sobre alimentos, la regulación del régimen de relación directa y regular y, por último, los pactos amistosos de separación ${ }^{100}$.

Respecto de las relaciones mutuas entre los cónyuges, pueden pactar el régimen patrimonial del matrimonio, su separación, presentar un acuerdo completo y suficiente en los juicios de separación o divorcio y celebrar acuerdos sobre compensación económica.

De esta forma, se puede afirmar que los cónyuges pueden celebrar acuerdos en las capitulaciones matrimoniales, antes y en el acto de la celebración del matrimonio, y también pueden sustituir el régimen durante el matrimonio (art. 1715 y ss. del $C C$ ).

Los denominados pactos amistosos de separación ${ }^{101}$ que pueden celebrar los cónyuges con ocasión de la separación de hecho, que más bien podríamos denominar separación convencional, se refieren a todas las principales materias de familia (arts. 21 y 22 de la NLMC). Es necesario diferenciar estos pactos amistosos de separación del acuerdo completo, que es exigido por nuestro legislador para solicitar de común acuerdo la separación judicial o el divorcio y del acuerdo sobre compensación económica. Estos pactos amistosos de separación están dispuestos en forma bastante general por la NLMC, habilitan a los cónyuges para regular sus relaciones mutuas y las materias concernientes a los hijos. Sin embargo, nada dice la NLMC respecto de la edad de los cónyuges, de las formalidades de los acuerdos o si es necesaria la intervención del juez. Solo que

\footnotetext{
${ }^{99}$ LePIN (2013a), p. 96.

${ }^{100}$ LePIN (2012), p. 11.

${ }^{101}$ Carbonnier (1961), p. 233 y ss.
} 
dichos acuerdos deben respetar los derechos que tengan el carácter de irrenunciables (art. 22 inc. $2^{\circ}$ de la NLMC).

Otro tipo de pacto es el acuerdo completo y suficiente, denominado por los españoles "convenio regulador"102. Exigido por el artículo 55 de la NLMC, que permite a los cónyuges solicitar de común acuerdo el divorcio, siempre que acrediten un plazo de cese de convivencia durante un lapso mayor de un año, y acompañen un acuerdo que regule en forma completa y suficiente sus relaciones mutuas y con respecto a sus hijos.

Aunque la ley no lo dispone, se trata de un acto solemne. Es necesario que el convenio regulador conste por escrito, a lo menos por escritura privada (incluso, no existe, a nuestro juicio, inconveniente en que se incorpore en un otrosí del escrito de la demanda o solicitud de divorcio), ya que el artículo 55 de la NLMC señala en forma imperativa: "debe acompañarse" (la única forma es que conste por escrito), quedando, en consecuencia, como un requisito de la acción de divorcio de común acuerdo o, si se quiere, como una carga para las partes, ya que en la práctica los cónyuges pueden estar de acuerdo en el divorcio, pero no necesariamente lo estarán en las otras materias de familia que deben regular en el convenio ${ }^{103}$.

De esta forma, el acompañar el acuerdo completo y suficiente, es un requisito de admisibilidad de la demanda de divorcio por cese efectivo 46 de la convivencia solicitada de común acuerdo por los cónyuges.

La NLMC, además, permite a los cónyuges regular la procedencia del derecho a compensación económica, su monto y la forma de pago, de forma tal que expresamente les reconoce la libertad y autonomía para regular esta materia. La NLMC les otorga la más amplia libertad para determinar la procedencia, cuantía y forma de pago de la compensación económica ${ }^{104}$. Así fluye de lo dispuesto en el artículo 63 de la NLMC, que utiliza la expresión "serán convenidos por los cónyuges"; y también de lo dispuesto en el artículo 64 de la NLMC, que reitera la misma idea al señalar: "a falta de acuerdo, corresponderá al juez determinar la procedencia de la compensación y fijar su monto"105.

Respecto a las relaciones de los padres con los hijos, se pueden celebrar acuerdos sobre el cuidado personal, relación directa y regular (incluso a favor de los abuelos), la patria potestad y los alimentos.

La ley $\mathrm{N}^{\circ} 20.680$ permite que los padres puedan regular la atribución $\mathrm{y}$ forma de ejercicio del cuidado personal de sus hijos, en conformidad al artículo 225 inciso $1^{\circ}$ del Código Civil, pudiendo atribuir su ejercicio de modo exclusivo a uno de ellos, o pactar alguna forma de ejercicio com-

${ }^{102}$ Arts. 81, 86 y 90 del Código Civil español.

${ }^{103}$ LEPIN (2013a), p. 99.

${ }^{104}$ Cfr. Lepin (2010), p. 136.

${ }^{105}$ LePIN (2013a), pp. 100-101. 
partido. Se trata de una manifestación de la autonomía de la voluntad de los padres, acuerdo que se va a manifestar por escritura pública o acta extendida ante cualquier oficial del Registro Civil, subinscrita al margen de la inscripción de nacimiento dentro de los treinta días siguientes a su otorgamiento. No se requiere aprobación judicial, como en el caso de las pensiones de alimentos ${ }^{106}$.

De igual forma, se puede establecer el régimen comunicacional entre el padre no custodio y su hijo, de acuerdo con el artículo 229 del Código Civil, que se remite a las formas establecidas del artículo 225 del mismo cuerpo legal.

En cambio, respecto del régimen comunicacional con los abuelos el acuerdo no exige solemnidades, tampoco dispone si deben suscribir dicho acuerdo ambos padres y el o los abuelos (artículo 229-2 del Código Civil).

En el caso de la patria potestad, el acuerdo entre los padres para atribuir el ejercicio a uno de ellos o ejercerlo en forma conjunta, mediante escritura pública o acta extendida ante cualquier oficial del Registro Civil, subinscrita al margen de la inscripción de nacimiento, dentro de los treinta días siguientes a su otorgamiento (arts. 244 y 245 del $C C$ ).

Por último, la ley permite regular los alimentos, ya sean menores o mayores, en una transacción aprobada por el tribunal de familia (art. 2451 del $C$ ). El juez aprobará la transacción si señala el monto, la fecha y el lugar del pago (artículo 11 de la ley $\mathrm{N}^{\circ} 14.908$ ).

\section{INTERVENCIÓN MÍNIMA DEL ESTADO}

Estrechamente relacionado con el principio de autonomía de la voluntad se encuentra el de intervención mínima del Estado. Coherente con lo que venimos diciendo en cuanto al respeto de los derechos fundamentales de los individuos como la igualdad, libertad y protección de la vida privada.

De esta forma, el Estado va intervenir, por intermedio de la justicia de familia, cada vez que resulte necesario hacerlo, es decir, en todos aquellos casos en que las partes no logran solucionar de mutuo acuerdo sus conflictos familiares, o en los casos que sea necesario actuar para proteger a los más débiles, como en supuestos de violencia intrafamiliar o vulneración de los derechos de los niños, niñas o adolescentes.

Así, según Rodrigo Barcia:

"este principio que viene abriéndose paso en la doctrina y la legislación especialmente en el Derecho comparado, consiste en

${ }^{106}$ LePIN (2014a), p. 144. 
que el Estado no puede intervenir a través de sus órganos en la familia contra la voluntad de la propia familia, sino en casos graves o extremos" 107 .

En los procedimientos de familia priman los principios de inmediación, actuación de oficio y búsqueda de soluciones colaborativas entre partes, que reflejan claramente lo sostenido, pretendiendo un justo equilibro entre la intervención judicial de oficio y la solución del conflicto por las propias partes (art. 9 de la LTF).

De la misma forma, la LTF dispone que la intervención judicial de oficio deberá observarse respecto de medidas destinadas a otorgar protección a los niños, niñas y adolescentes y a las víctimas de violencia intrafamiliar (art. 13 de la LTF). En este sentido, en el abandono del procedimiento en este tipo de materias, se debe citar a las partes bajo apercibimiento de continuar el procedimiento y resolver de oficio (art. 21 de la LTF).

En cuanto a la búsqueda de soluciones del conflicto familiar, los tribunales de familia deben privilegiar las soluciones acordadas por ellas (art. 14 de la LTF). En la misma línea, se debe promover en la audiencia preparatoria, la mediación y la conciliación (art. $61 \mathrm{~N}^{\circ} 4$ y $\mathrm{N}^{\circ} 5$ de la LTF).

Como se ha señalado, la mediación es una forma alternativa de resolución de conflictos en que las partes, ayudadas por un tercero (mediador), solucionan mediante acuerdos su conflicto (art. 103 de la LTF). Incluso, en ciertas materias como alimentos, cuidado personal y relación directa y regular, el procedimiento de mediación debe realizarse en forma previa y obligatoria (arts. 106 y 57 inciso $2^{\circ}$ de la LTF).

La LTF regula procedimientos especiales, en el título IV, para proteger a los niños, niñas y adolescentes tendientes a la protección de sus derechos cuando se encontraren amenazados o vulnerados (arts. 68 a 80 bis de la LTF) y en los casos de actos de violencia intrafamiliar (arts. 81 a 101 de la LTF). Además de una completa potestad cautelar genérica (art. 22 de la LTF) y especial (arts. 71 y 92 de la LTF).

En el mismo sentido, la NLMC, el juez debe instar a las partes a conciliación (medio alternativo de resolución, en que las partes logran solucionar sus conflictos mediante acuerdos sometidos a la aprobación del tribunal), sobre todas las materias de familia (arts. 67 y 69 de la NLMC), incluso sobre materias no sometidas a conocimiento del tribunal (art. 90 de la NLMC).

La misma idea se aprecia, por ejemplo, respecto de la compensación económica. En principio, el legislador reconoce la más amplia libertad a los cónyuges para determinar la procedencia, cuantía y forma de pago

${ }^{107}$ Barcia (2011), p. 26. 
de la compensación económica ${ }^{108}$. Así fluye de lo dispuesto en el art. 63 y 64 de la NLMC. De este modo, en subsidio y solo a falta de acuerdo, debe intervenir el juez para determinar la procedencia de la prestación compensatoria, fijar su monto.

Por último, la ley $\mathrm{N}^{\circ} 20.680$ incorpora como primera alternativa los acuerdos de las partes en materia de efectos de la filiación y en los casos que no sea posible esta solución, recurrir a la justicia de familia.

\section{CONCLUSIONES}

Los actuales principios del Derecho de Familia son fruto de la incorporación de las progresivas reformas enunciadas, las que han sido generadas a la luz de los tratados sobre derechos humanos, aprobados por nuestro país en los últimos años, y que en virtud de lo que dispone el artículo $5^{\circ}$ de la Constitución Política de la República, constituyen, por una parte, un límite al ejercicio de la soberanía y, por otra, un deber del Estado y de sus órganos, de promover y respetar los derechos esenciales que emanan de la naturaleza humana.

A nuestro juicio, la profundas transformaciones del Derecho de Familia determinan los nuevos principios, que se han ido configurando con el tiempo, no responden a reformas planificadas ni a una legislación coherente, sino que, más bien, a intentar solucionar problemas específicos.

En este sentido, todavía falta avanzar en la regulación de otras formas de familia, como las relaciones de convivencia, familias ensambladas, y sigue pendiente el debate sobre el matrimonio homosexual. El Estado de Chile, sigue todavía en deuda con los derechos civiles de la mujer casada en sociedad conyugal. Además de avanzar en la aplicación de los principios como el interés superior del niño o del cónyuge más débil.

En un escenario donde se garantiza el pleno ejercicio de los derechos humanos de los ciudadanos, incluso en el ámbito familiar, donde priman el pleno ejercicio de la libertad y la igualdad entre los integrantes del grupo familiar, son estos los primeros llamados a resolver sus conflictos. De manera que los integrantes de la familia pueden celebrar pactos sobre casi la totalidad de las materias de familia. Solo en los casos de las pensiones de alimentos dichos acuerdos requieren aprobación judicial.

Con respecto a los pactos o acuerdos en materia de familia, estimamos necesario plantear una teoría del acto jurídico de familia, en que se revisen aspectos muy importantes como el valor de dichos acuerdos,

${ }^{108}$ Cfr Lepin (2010), p. 136. 
solemnidades, modalidades, vicios del consentimiento, capacidad e ineficacia, entre otros.

Por último, el principio de intervención mínima del Estado implica que el Estado va intervenir, por intermedio de la justicia de familia, solo cuando resulte necesario o indispensable hacerlo, es decir, en todos aquellos casos en que las partes no logren solucionar de mutuo acuerdo sus conflictos familiares, o en los casos que sea necesario actuar para proteger a los más débiles, como en los supuestos de violencia intrafamiliar o vulneración de los derechos de los niños, niñas y adolescentes.

\section{Bibliografía CITADA}

Abeliuk Manasevich, René (2009). "Evolución de la legislación civil chilena en materia de derecho de familia y sucesorio", en Enrique AlCalde y Hugo FÁbrega (coords.), Estudios Jurídicos en Homenaje al Profesor Pablo Rodríguez Grez, Santiago: Ediciones Universidad del Desarrollo.

Alessandri Rodríguez, Arturo (1941). Derecho de Familia. Santiago: Editorial Zamorano y Caperán.

Alexy, Robert (2008). Teoría de los derechos fundamentales. $2^{\mathrm{a}}$ ed. (trad.) Ernesto Garzón. Madrid: Centro de Estudios Políticos y Constitucionales.

Álvarez Cruz, Raúl (1998). La filiación y otras reformas al Código Civil. Santiago de Chile: s/e.

Barcia Lehmann, Rodrigo (2011). Fundamentos del derecho de Familia y de la Infancia. Santiago: Editorial Thomson Reuters.

Barrientos Grandon, Javier (2011). Derecho de Las Persona. El derecho Matrimonial. Santiago: Editorial LegalPublishing.

Bossert, Gustavo y Eduardo Zannoni, (2007). Manual de derecho de familia. $6^{\mathrm{a}}$ ed. Buenos Aires: Editorial Astrea.

Carbonnier, Jean (1961). Derecho Civil. (trad.) Manuel Zorrilla. Barcelona: Editorial Bosch, tomo I.

Cillero Bruñol, Miguel (2007). "El interés superior del niño en el marco de la Convención Internacional sobre los Derechos del Niño". Revista Justicia y Derechos del Niño (UNICEF), N 9. Santiago.

Córdoba, Marcos (dir.) (2005). Derecho de Familia. Parte General. Buenos Aires: Editorial La Ley.

Corral Talciani, Hernán (1994). Familia y Derecho. Santiago: Ediciones Universidad de Los Andes.

Corral Talciani, Hernán (edit.) (2000). Derecho sucesorio actual y adjudicación de la vivienda familiar, Cuadernos de Extensión Jurídica $\mathrm{N}^{\circ}$ 4, Santiago: Ediciones Universidad de los Andes. 
Corral Talciani, Hernán (2005). La vivienda familiar en la sucesión del cónyuge. Santiago: Editorial Jurídica de Chile.

Corral Talciani, Hernán (2007). Bienes Familiares y Participación en los gananciales. $2^{a}$ ed. Santiago: Editorial Jurídica de Chile.

Del Picó Rubio, Jorge (2010). Derecho Matrimonial Chileno. Santiago: AbeledoPerrot-LegalPublishing.

Díez-Picazo y Ponce de León, Luis (1989). "La figura del convenio regulador en el marco del negocio jurídico familiar y de los principios constitucionales del derecho de familia", en AA.VV., Convenios reguladores de las relaciones paternofiliales y patrimoniales en las crisis del matrimonio. $2^{\mathrm{a}}$ ed. Pamplona: Ediciones Universidad de Navarra.

Díez-Picazo, Luis y Antonio Gullón (2006). Sistema de Derecho Civil. $10^{\mathrm{a}}$ ed. Madrid: Editorial Tecnos, vol. IV.

Domínguez Hidalgo, Carmen (2005). "Los principios que informan el Derecho de Familia chileno: su formulación clásica y su revisión moderna". Revista Chilena de Derecho, vol. 32, N² 2. Santiago.

Dworkin, Ronald (1989). Los derechos en serio. (trad.) Marta Guastavino. Barcelona: Editorial Ariel.

Figueroa Yáñez, Gonzalo (1995). Persona, pareja y familia. Santiago: Editorial Jurídica de Chile.

Giordano, Verónica (2010). "La ampliación de los derechos civiles de las mujeres Chile (1925) y Argentina (1926)". Mora (B. Aires), vol. 16 N$^{\circ} 2$. Buenos Aires.

Gómez de la Torre Vargas, Maricruz (2007). El sistema filiativo chileno. Santiago: Editorial Jurídica de Chile.

Gómez de la Torre Vargas, Maricruz (2009). "Principios que informan la ley de matrimonio civil". Revista Diké, vol. $1 \mathrm{~N}^{\circ} 1$. Santiago.

Guerrero Becar, José (2008). "Menoscabo y compensación económica. Justificación de una visión asistencial”, Revista Derecho, vol. 21, N 2. Valdivia.

Hübner GuZMán, Ana María (2005). "La nueva Ley de matrimonio civil: panorama y estructura general”, en Anastasía Assimakópulos y Hernán CORRAL (eds.), Matrimonio civily divorcio, análisis crítico y criterios para la aplicación de la Ley $N^{\circ}$ 19.947. Santiago: Universidad de Los Andes.

Lepin Molina, Cristián (2010). La compensación económica. Efecto patrimonial de la terminación del matrimonio. Santiago: Editorial Jurídica de Chile.

Lepin Molina, Cristián (2012). "La autonomía de la voluntad y la protección del cónyuge más débil en la determinación y formas de pago de la compensación económica". Revista Ius et Praxis, año 18, $\mathrm{N}^{\circ} 1$. Talca.

Lepin Molina, Cristián (2013a). "Autonomía de la voluntad y los acuerdos conyugales", en Carmen Domínguez et al. (coords.), Estudios de Derecho Civil VIII, Santiago: Editorial Thomson Reuters. 
Lepin Molina, Cristián (2013b). "El principio de protección del cónyuge más débil en el moderno Derecho de Familia". Revista Chilena de Derecho, vol. 40, $\mathrm{N}^{\circ}$ 2. Santiago.

Lepin Molina, Cristián (2013c). "Los principios del Derecho sucesorio chileno", Revista de Derecho Familiar "Pater familias" (Facultad de Derecho, Universidad Nacional Autónoma de México), año 1, $\mathrm{N}^{\circ} 1$. México.

Lepin Molina, Cristián (2014a). "Modificaciones a los efectos de la filiación. Una cuestión de principios". Revista de Derecho de Familia, Thomson Reuters, ${ }^{\circ} 1$. Santiago.

Lepin Molina, Cristián (2014b). Compendio de normas de Derecho de Familia. Santiago: Thomson Reuters.

Méndez Costa, María Josefa et al. (2008). Derecho de Familia. Buenos Aires: Editorial Rubinzal-Culzoni.

Meza Barros, Ramón (1989). Manual de Derecho de la Familia. Santiago: Editorial Jurídica de Chile, tomo I.

MuÑoz SÁnchez, Andrea (1999). "Aspectos sucesorios de la reforma", en AA.VV., El nuevo estatuto filiativo y las modificaciones al derecho sucesorio, a la luz de las normas y principios de la ley $N^{\circ}$ 19.585. Santiago: Servicio Nacional de la Mujer.

OrRego Acuña, Juan (2007). Los alimentos en el Derecho Chileno. Santiago: Editorial Metropolitana, Santiago.

Ramos Pazos, René (2005). Derecho de Familia. $5^{\text {a }}$ ed. Santiago: Editorial Jurídica de Chile, tomo I.

Rioseco EnríQuez, Emilio (1956). "El Código Civil y la evolución del Derecho de Familia". Revista de Derecho Universidad de Concepción, N 98. Concepción.

Roca, Encarna (1999). Familia y cambio social (De la "casa" a la persona). Madrid: Cuadernos Civitas.

Rodríguez Grez, Pablo, Ley de matrimonio civil, en: www.abogados.cl. [Fecha de consulta: 10 de abril de 2014].

Rossel SaAvedra, Enrique (1958). Manual de Derecho de Familia. Santiago: Editorial Jurídica de Chile.

Schmidt Hotт, Claudia (2005). La constitucionalización del derecho de familia, en María Dora Martinic y Mauricio Tapia (dirs.), Sesquicentenario del Código Civil de Andrés Bello. Pasado, presente y futuro. Santiago: LexisNexis, tomo II.

Somarriva Undurraga, Manuel (1963). Derecho de Familia. $2^{\text {a }}$ ed. Santiago: Editorial Nascimento.

Soто KLoss, Eduardo (1994). "La Familia en la constitución política". Revista Chilena de Derecho, vol. $21 \mathrm{~N}^{\circ}$ 3. Santiago.

Veloso Valenzuela, Paulina (2006). "Algunas reflexiones sobre la compensación económica". Revista Actualidad Jurídica, $\mathrm{N}^{\circ}$ 13. Santiago.

Vidal Olivares, Álvaro (2006). "La compensación por menoscabo económico en la ley de matrimonio civil", en Álvaro Vidal Olivares (coord.), El nuevo 
Derecho chileno del matrimonio (Ley $N^{\circ} 19947$ de 2004). Santiago: Editorial Jurídica de Chile.

Zannoni, Eduardo (2006). Derecho de Familia. $5^{\mathrm{a}}$ ed. Buenos Aires: Editorial Astrea.

\section{Normas citadas}

\section{Código Civil.}

Código de Procedimiento Civil.

Constitución Política de la República.

Convención Americana sobre Derechos Humanos.

Convención Interamericana para Prevenir, Sancionar y Erradicar la Violencia contra la Mujer.

Convención sobre la Eliminación de Todas las Formas de Discriminación contra la Mujer.

Convención sobre los Derechos de los Niños

Declaración Universal de los Derechos Humanos.

Ley N ${ }^{\circ} 4.808$, sobre Registro Civil, Diario Oficial, 10 de febrero de 1930.

Ley $\mathrm{N}^{\circ} 19.620$, dicta normas sobre adopción de menores, Diario Oficial, 5 de agosto de 1999.

Ley $N^{\circ}$ 19.947, Nueva Ley de Matrimonio Civil, Diario Oficial, 17 de mayo de 2004.

Ley $N^{\circ}$ 19.968, crea los Tribunales de Familia, Diario Oficial, 30 de agosto de 2004.

Ley $\mathrm{N}^{\circ} 20.680$, introduce modificaciones al Código Civil y a otros cuerpos legales, con el objeto proteger la integridad del menor en caso de que sus padres vivan separados, Diario Oficial, 21 de junio de 2013.

Pacto Internacional de Derechos Civiles y Políticos.

\section{Jurisprudencia citada}

[No se consignan partes. Declaración de susceptibilidad de adopción (1)] (2012): Corte de Apelaciones de Santiago, 2 de octubre de 2012 (apelación), Legal Publishing $\mathrm{N}^{\circ}$ CL/JUR/2168/2012.

[No se consignan partes. Declaración de susceptibilidad de adopción (2)] (2012): Corte de Apelaciones de Valparaíso, 9 de octubre de 2012 (apelación), Legal Publishing $\mathrm{N}^{\circ}$ CL/JUR/2257/2012.

Álvarez Quena con Raimilla Espinoza (2007): Corte de Apelaciones de Valdivia, 23 de julio de 2007 (casación de oficio), Legal Publishing $N^{\circ} 36677$.

Calderón Barraza con Munizaga Castro (2006): Corte de Apelaciones de La Serena, 30 de marzo de 2006 (casación de oficio), Legal Publishing $\mathrm{N}^{\circ} \mathrm{CL} / \mathrm{JUR} /$ $1117 / 2006$.

Durán Espinoza con Miranda Bustos (2011): Corte Suprema, 23 de mayo de 2011 (casación de oficio), Legal Publishing $\mathrm{N}^{\circ} 49223$. 
Espina Brisso con Varela Lagos (2010): Corte Suprema, 16 de marzo de 2010 (casación en el fondo), Micro Juris $\mathrm{N}^{\circ}$ MJJ23242.

Flores Sepúlveda con Mora Mora (2006): Corte de Apelaciones de Talca, 13 de septiembre de 2006 (casación en la forma), Legal Publishing $\mathrm{N}^{\circ} 35117$.

Godoy Saldaña y otros con Director Regional del Servicio de Registro Civil e Identificación Región del Bío Bío (2014): Corte de Apelaciones de Concepción, 17 de julio de 2014 (protección), Legal Publishing N CL/JUR/4645/2014.

González Navarro con Herrera Valencia (2012): Corte Suprema, 27 de febrero de 2012, Legal Publishing $\mathrm{N}^{\circ} 59062$.

Henzi con Plaza Reveco (2011): Corte de Apelaciones de Temuco, 19 de abril de 2011 (apelación), Legal Publishing $\mathrm{N}^{\circ} 49248$.

Hidalgo Muñoz con González Barahona (2014): Corte Suprema, 13 de enero de 2014 (casación en el fondo), Legal Publishing $\mathrm{N}^{\circ} \mathrm{CL} / \mathrm{JUR} / 75 / 2014$.

J.V.R. con L.A.S.V. (2014): Corte Suprema, 11 de febrero de 2014 (casación en el fondo), Legal Publishing $\mathrm{N}^{\circ} \mathrm{CL} / \mathrm{JUR} / 223 / 2014$.

Leiva Falinich con Departamento de Extranjería y Migración (2013): Corte Suprema, 23 de enero 2013 (apelación amparo), Legal Publishing $\mathrm{N}^{\circ} \mathrm{CL} / \mathrm{JUR} /$ $162 / 2013$.

López Allende con Atala Riffo (2004): Corte Suprema, 31 de mayo de 2005 (queja), Legal Publishing $\mathrm{N}^{\circ} 30299$.

54 Olaechea Vásquez con Departamento de Extranjería y Migración (2014), Corte Suprema: 20 de mayo de 2014 (apelación amparo), Legal Publishing $\mathrm{N}^{\circ} \mathrm{CL} / \mathrm{JUR} /$ $2534 / 2014$

Malebrán Castañeda con Corral Gallardo (2011): Corte Suprema, 23 de mayo de 2011 (casación en el fondo), Legal Publishing N $^{\circ} 49556$.

Massis Nazar con Sánchez Luengo (2010): Corte Suprema, 24 de junio de 2010, Legal Publishing $\mathrm{N}^{\circ} 45498$.

Meza Saavedra con De la Rivera Araya (2010): Corte Suprema, 16 de agosto de 2010 (casación en el fondo), Legal Publishing $\mathrm{N}^{\circ} 45255$.

Ministerio Público con Ojeda Ortiz (2009): Corte de Apelaciones de La Serena, 27 de marzo de 2009 (apelación), Legal Publishing N ${ }^{\circ}$ CL/JUR/8525/2009.

Morales García con Departamento de Extranjería y Migración (2013): Corte de Apelaciones de Santiago, 21 de enero de 2013 (amparo), Legal Publishing $\mathrm{N}^{\circ} \mathrm{CL} / \mathrm{JUR} / 145 / 2013$.

Plaza Oviedo con [no se consigna] (2010): Corte Suprema, 16 de septiembre de 2010 (casación en el fondo), Legal Publishing $\mathrm{N}^{\circ}$ CL/JUR/16842/2010.

Rojas Carvajal con Román Beltraim (2008): Corte de Apelaciones de Valparaíso, 22 de febrero de 2008 (apelación), Legal Publishing N $^{\circ}$ CL/JUR/7406/2008.

Román Hartard y otro con [no se consigna] (2014): Corte Suprema, 8 de abril de 2014 (exequátur), Legal Publishing $\mathrm{N}^{\circ} \mathrm{CL} / \mathrm{JUR} / 1061 / 2014$.

Sáez con Fisco de Chile (2001): Corte Suprema, 21 de junio 2001 (inaplicabilidad), rol N ${ }^{\circ} 862-2000$. 
Soufien Lahouel con Ministerio de Relaciones Exteriores (2014): Corte Suprema, 12 de junio de 2014 (apelación amparo), Legal Publishing $\mathrm{N}^{\circ} \mathrm{CL} / \mathrm{JUR}$ / 3798/2014.

Suárez Cabrera con Larrañaga González (2008): Corte de Apelaciones de Valparaíso, 10 de abril de 2008 (apelación), Legal Publishing $\mathrm{N}^{\circ} \mathrm{CL} / \mathrm{JUR}$ / $5435 / 2008$.

Tirado Guevara con Departamento de Extranjería y Migración (2006): Corte Suprema, 7 de agosto de 2006 (apelación amparo), Legal Publishing $\mathrm{N}^{\circ} \mathrm{CL} / \mathrm{JUR}$ / 5535/2006.

Varela Walker con Montes Larraín (2003): Corte de Apelaciones de Santiago, 7 de octubre de 2004, rol N 7166-2003.

Vargas Aguirre con Delgado Adaros (2005): Corte Apelaciones de La Serena, 2 de diciembre de 2005 (consulta), Legal Publishing N CL/JUR/1911/2005.

Velásquez Basaez con Zimmert Michel (2014): Corte de Apelaciones de Concepción, 20 de mayo de 2014 (apelación), Legal Publishing $\mathrm{N}^{\circ} \mathrm{CL} / \mathrm{JUR}$ 2551/2014.

Von Elgott con Baumgartner (2012): Corte de Apelaciones de Valdivia, 16 de febrero de 2012 (apelación), Legal Publishing $\mathrm{N}^{\circ} 58979$.

\section{Historia de la ley}

Biblioteca del Congreso nacional (2004), Historia de la Ley $N^{\circ} 19.947$, disponible en www.bcn.cl/obtienearchivo?id=recursoslegales/10221.3/606/4/HL19947. pdf [Fecha de consulta: 12 de septiembre de 2014]. 